\title{
THE
}

\section{Elements of paradoxes in supply chain management literature: A systematic literature review}

Jiayuan Zhang

University of Rhode Island

Mehmet G. Yalcin

University of Rhode Island, mgyalcin@uri.edu

Douglas N. Hales

University of Rhode Island, dhales@uri.edu

Follow this and additional works at: https://digitalcommons.uri.edu/cba_facpubs

The University of Rhode Island Faculty have made this article openly available. Please let us know how Open Access to this research benefits you.

This is a pre-publication author manuscript of the final, published article.

Terms of Use

This article is made available under the terms and conditions applicable towards Open Access Policy Articles, as set forth in our Terms of Use.

\section{Citation/Publisher Attribution}

Zhang J., Yalcin, M. G., Hales, D. N. (2020). Elements of Paradoxes in Supply Chain Management Literature: A Systematic Literature Review. International Journal of Production Economics, 232C, 107928. https://doi.org/10.1016/j.jpe.2020.107928

Available at: https://doi.org/10.1016/j.ijpe.2020.107928 


\section{Journal Pre-proof}

Elements of paradoxes in supply chain management literature: A systematic literature review

Jiayuan Zhang, Mehmet G. Yalcin, Douglas N. Hales

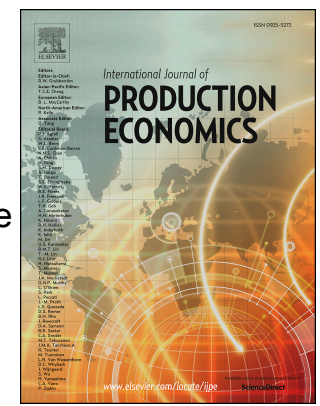

PII:

S0925-5273(20)30283-8

DOI:

https://doi.org/10.1016/j.ijpe.2020.107928

Reference: PROECO 107928

To appear in: International Journal of Production Economics

Received Date: 14 December 2019

Revised Date: 28 June 2020

Accepted Date: 14 September 2020

Please cite this article as: Zhang, J., Yalcin, M.G., Hales, D.N., Elements of paradoxes in supply chain management literature: A systematic literature review, International Journal of Production Economics (2020), doi: https://doi.org/10.1016/j.ijpe.2020.107928.

This is a PDF file of an article that has undergone enhancements after acceptance, such as the addition of a cover page and metadata, and formatting for readability, but it is not yet the definitive version of record. This version will undergo additional copyediting, typesetting and review before it is published in its final form, but we are providing this version to give early visibility of the article. Please note that, during the production process, errors may be discovered which could affect the content, and all legal disclaimers that apply to the journal pertain.

C 2020 Published by Elsevier B.V. 
Elements of Paradoxes in Supply Chain Management Literature: A Systematic Literature Review

\section{CRediT author statement}

Jiayuan Zhang: Conceptualization, Methodology, Formal analysis, Investigation, Data curation, Writing- Original draft preparation, Writing- Reviewing and Editing, Visualization. Mehmet G. Yalcin: Conceptualization, Methodology, Formal analysis, Investigation, Writing- Original draft preparation, Writing- Reviewing and Editing, Visualization, Supervision, Project administration. Douglas N. Hales: Writing- Reviewing and Editing. 
Elements of Paradoxes in Supply Chain Management Literature: A Systematic Literature Review

\author{
Jiayuan Zhang \\ College of Business \\ University of Rhode Island \\ 7 Lippitt Rd., Kingston, RI 02881 \\ U.S.A \\ Email: jiayuanzhang@uri.edu
}

Mehmet G. Yalcin

College of Business

University of Rhode Island

7 Lippitt Rd., Kingston, RI 02881

U.S.A.

Email: mgyalcin@uri.edu (Corresponding author)

Phone number: 401-874-4247

Douglas N. Hales

College of Business

University of Rhode Island

7 Lippitt Rd., Kingston, RI 02881

U.S.A.

Email: dhales@uri.edu

* This research does not receive any specific grant from funding agencies in the public, commercial, or not-for-profit sectors. 


\title{
Elements of Paradoxes in Supply Chain Management Literature: A Systematic Literature Review
}

\begin{abstract}
This study reports the results of a systematic literature review investigating paradoxes in supply chain management. This issue is important because supply chain practitioners frequently face paradoxes in industry with little direction provided in supply chain literature. Investigating the years 1997 through 2019, we identified 64 articles as the basis of our research containing a total of 68 unique paradoxes. In identifying the paradox elements (PEs), we adopted paradox theory (PT) as the base theoretical approach, which was utilized in only 7 of the articles. We also employed contingency theory, institutional complexity theory, and complexity theory to support our findings. For each paradox, we also extracted and summarized managerial insights for practitioners. This study addresses the emergent needs of investigating paradoxes in the supply chain management domain to extend the use of PT and complimentary theories that can aide practitioners in how to efficiently manage the paradoxes they encounter in industry.
\end{abstract}

Keywords: Paradox theory, Paradox elements, Systematic literature review, Supply chain management, Paradox

\section{Introduction}

Since paradox theory (PT) (Lewis, 2000; Smith and Lewis, 2011) was introduced in supply chain literature (Matthews et al., 2016), the theory continues to receive scholarly attention (Sandberg, 2017; Xiao et al., 2018; BrixAsala et al., 2018; Coscieme et al., 2019). One of the drivers of the popularity of PT in the field is that practitioners increasingly face paradoxes in managing supply chains. These paradoxes take many forms such as the contradictory goals in operations to increase inventory levels, improving service levels and the pressures to simultaneously lower inventory cost (Kull et al., 2013). It also applies to transportation where, adding additional routes to improve delivery effectiveness while simultaneously observing a decrease in network efficiency (a.k.a. Braess paradox) (Frank, 1981). In procurement, tensions exist between short-term supply partnerships to improve flexibility and long term, high-involvement supply partnerships to increase effectiveness (Cerruti et al., 2016). In addition, globalization and sustainability issues in supply chains also accelerate the adoption of PT (Coscieme et al., 2019; Brix-Asala et al., 2018). 
Since 2000, PT has evolved into a metatheory (Lewis, 2000; Smith and Lewis, 2011; Lewis and Smith, 2014; Smith et al., 2017), meaning that it can explain paradoxes across a number of contexts. The literature defines a paradox as "persistent contradictions between interdependent elements" (Lewis, 2000, p.760), and handling these contradictory and interdependent elements properly can provide new opportunities for organizations to grow (Smith and Lewis, 2011; Lewis and Smith, 2014; Smith et al., 2017). While fierce global competition that is fueled by innovation and sustainability pressures creates uncertainties, PT provides a "critical theoretical lens to understand and to lead contemporary organizations" (Smith and Lewis, 2011, p.398). It has the potential to address interwoven organizational challenges and suggests effective both/and management strategies (Lewis and Smith, 2014). However, we find that the use of PT is relatively limited in the supply chain field, indicating that supply chain management (SCM) scholars and practitioners may not be familiar with this formal theoretical framework that examines paradoxes. Given the apparent increase in conflicting objectives in industry, it signals a need to extend use of PT to benefit practitioners.

Previous literature introduced the PT to the SCM context (Matthews et al., 2016; Coscieme et al., 2019; BrixAsala et al., 2018) to identify paradoxes in global supply chain management (Matthews et al., 2016) and paradoxes in sustainability (Xiao et al., 2019). To contribute to the literature, we identify a list of paradox elements (PEs), which are single elements that are perceived to be part of a larger set of elements that form a paradox. Specifically, this study applies PT to summarize and to classify PEs in SCM literature. Paradox theorists offer several research agendas (Schad et al., 2016; Smith et al., 2017, Schad et al., 2019) that point to the potential of PT across diverse research streams of management science. In this study, we follow this lead and conduct a systematic literature review (SLR) to examine how PT relates to the SCM literature.

The SLR method has been increasingly used in SCM in recent years (Chakuu, Masi, and Godsell, 2019; Masae et al., 2020; Glock et al., 2017). Chakuu, Masi, and Godsell discuss SLR as superior to other review methods because it relies on replicable and transparent evidence, which leads to reduced bias during the analysis and summarization stages of the literature. Glock et al. (2017) mentioned that SLR enables readers to reproduce sample generation and evaluation, as well as to interpret and to follow up on the findings. Our study uses the same SLR approach that Durach et al. (2017) proposes for use in the SCM domain. In doing so, we also address the call of rigorous and transparent SLR in SCM (Thomé, Scavarda, and Scavarda, 2016). 
Because the use of PT in SCM is relatively new, this study also examines complimentary theories that explain similar phenomena such as complexity theory (Nilsson, 2006; Nilsson and Gammelgaard, 2012; Nilsson, 2019), institutional complexity theory (Greenwood et al., 2011; Smith and Tracey, 2016), and contingency theory (Fiedler, 2005; Scott and Davis, 2015; Lewis and Smith, 2014). This allows us to investigate the unique characteristics of PT that focus on paradoxes that aren't fully explained by other perspectives, as well as those that overlap with PT. Studies that promote this approach (Halldórsson et al., 2007; Halldórsson, Hsuan, and Kotzab, 2015) have discussed how the use of complementary theoretical perspectives can benefit the SCM field where the main theory can be supported by one or more complimentary theories (Halldórsson et al., 2007).

This literature review also addresses the necessity of investigating the paradoxes currently known in SCM, including conflicting objectives. Conflicting objectives are characterized as PEs. Lewis (2000) discussed that choosing among competing objectives might give a temporary performance relief to the firm, but in order to achieve long term sustainable goals, a firm should acknowledge the existence of PEs in the system and attend to them simultaneously. Identifying and categorizing PEs pave the way for future scholars and practitioners to extend PT to explain phenomena that already exist in the literature and devise ways to manage the paradoxes. Applying complementary theoretical approaches provide alternative frameworks to study the PEs, in addition to PT. In doing so, our study builds on Sandberg's (2017) study who recommends extending PT beyond global sourcing to explain other topics in SCM in general.

This study makes several practical and theoretical contributions. First, we summarize the managerial insights on the paradoxes that can provide guidance for SCM practitioners to handle them more properly. Recognizing and balancing these PEs help practitioners increase the effectiveness of managing the supply chain and decision making. Second, our study is unique in that it summarizes the PEs in SCM domain by providing a list of PEs in the SCM literature, and extends the usage of PT in SCM. Third, in the interest of parsimony this is the first study to classify PEs into different paradox categories based on PT. In addition, we further code the PEs into different themes within each category based on expert opinion. Fourth, we apply complementary theoretical approaches (contingency theory, institutional complexity, and complexity perspective) to explain the PEs.

Our paper is structured as follows. We further introduce the PT in the next section. Then, we explain the SLR approach in the methodology section and continue with reporting our findings in the results section. At the end, we conclude with the presentation of further discussions, implications, and potential future research avenues. 


\section{Theoretical background}

\subsection{Paradox theory (PT) and paradox elements (PEs)}

PT defines paradox as "contradictory yet interrelated elements that seem logical in isolation, but which are irrational, inconsistent and even absurd when appearing simultaneously, and which persist over time" (Smith and Lewis, 2011, p.387). Lewis (2000) first explored paradoxes in organizations and provided a framework to investigate them. Lewis grouped paradoxes into learning, organizing, and belonging categories. A decade after this paradox framework (Lewis, 2000) was introduced, Smith and Lewis (2011) reviewed the paradox literature.

Highlighting the debates in paradox literature, the article extends the three paradox categories mentioned in Lewis (2000) and includes a fourth paradox category - performing paradox. Given the four categories of paradoxes, Smith and Lewis (2011) introduced six additional paradox categories derived from the combinations of the four paradox categories (performing, learning, organizing, and belonging). These additional six paradox categories are learningbelonging, learning-organizing, belonging-organizing, learning-performing, performing-belonging, and performing-organizing paradoxes (Smith and Lewis, 2011). Lewis and Smith (2014) suggest PT as a metatheoretical perspective and demonstrate how paradox studies examine tensions at different levels of analysis and leverage wideranging methods and theories. They argue that PT can serve as the theoretical framework to make sense of the tensions in an organization. Smith et al. (2017) arguably pin the phenomenon of paradox to ancient philosophy while citing that paradox research increased by ten percent per year between 1990 and 2014. Their studies build on early research conducted in psychoanalysis, communications, and macro sociology disciplines. The authors also add a collection of studies that advance the PT by positing that interdependent contradictions are inherent in human nature, its environment, as well as the constructs that we humans build (e.g. expansion-constriction, independencedependence, stability and change, empowerment and alienation, flexibility and control, exploration and exploitation, competition and collaboration). However, while PT has been widely studied and applied in the management literature, its application in SCM is limited. As Sandberg (2017) mentioned, although SCM scholars and practitioners have been aware of paradoxes, they have lacked a formal theoretical framework to identify and classify them. Therefore, we use PT to summarize and identify PEs, which are the single elements that are perceived as a part of greater set of elements that form paradox, in the SCM domain. 


\subsection{Paradox research in SCM}

We have identified seven articles that utilized PT for theoretical grounding. The articles are Longoni et al. (2019) and Xiao et al. (2019) in Journal of Supply Chain Management (JSCM), Brix-Asala et al. (2019) in Sustainability, Niesten and Stefan (2019) in International Journal of Management Review (IJMR), Wihelm and Sydow (2018) in JSCM, Sandberg (2017) in International Journal of Logistics Research and Applications (IJLRA), and Matthews et al. (2016) in JSCM. These studies provide valuable contributions toward extending PT into the SCM domain. While Xiao et al. (2019) and Brix-Asala et al. (2018) effectively demonstrate that uncharted territories, beyond trade-offs, exist within SCM, they identify several opportunities for future research. Even though "the two case studies only exemplify paradoxes inherent in global sourcing practices" (Sandberg, 2017, p.471), they pave the way for SCM scholars to improve the existing paradox framework applied from Smith and Lewis (2011). This not only advances the stages of importing PT into SCM, but also encourages paradox theorists to collect valuable feedback from SCM studies to improve generalizability and parsimony. The emergence of the studies on paradox research in SCM indicates the need for a thorough literature review to summarize the paradoxes in previous studies and provide future avenues for the application of PT in the field.

\subsection{Complementary theoretical approaches}

The complementary use of contingency theory, institutional complexity theory, and complexity theory with PT has been presented in previous studies (Lewis and Smith, 2014; Smith and Tracey, 2016; Nilsson and Christopher, 2018). Lewis and Smith (2014) compare the difference between contingency theory and PT on investigating the tensions. Simply put, PT seeks to answer how to engage A and B simultaneously, while contingency theory seeks to answer under what conditions should managers emphasize A or B. Complexity theory describes the interactions between A and B that cause feedback loops that can change both PEs, while institutional complexity theory says A and B can vary based on the environment in which they exist. Some of the PEs that we identified can be investigated under the contingency theory, for example, the paradox arising from international carbon foot-printing (PCS) standardization and the need to customize the PCS to meet national-level goals. Institutional complexity focuses on the situation in which organizations tackle irreconcilable institutional pressures and help identify pathways to make sense and operate under various social demands (Greenwood et al., 2011). Smith and Tracey (2016, p.455) conclude that "examining both institutional complexity theory and PT will result in rich, generative theorizing to better 
address key challenges in the world”. Complexity theory (Anderson, 1999; Philip, 1999; Nilsson, 2006; Nilsson and Gammelgaard, 2012) discusses that the essence of tensions that create disorder and subjectivity; epistemologically, of heuristics or anti-positivism; and technologically, of a transformative nature. Complexity theory focuses on bringing the transformative mindsets to study and handle the paradoxes in an ever-changing, iterative manner (Nilsson, 2006; Nilsson and Christopher, 2018).

To help investigate the PEs, several theoretical approaches can be applied as alternative or complimentary tools to PT to improve refutability. We investigate the PEs by introducing complementary theories and address the scarcity of formal theoretical frameworks to study paradoxes. Complexity theory addresses conflicting demands (Anderson, 1999; Philip, 1999; Nilsson, 2006; Nilsson, 2019). It describes a complex adaptive system that is selforganizing and the structure of it is determined by its agents. Applied to supply chains, it says that the structure of the network will evolve in ways that are not anticipated (Touboulic, Matthews, and Marques, 2018). Chae (2012) applies complexity theory to supply chains to investigate the simultaneous and conflicting demands between "short walk" and "long jump" in service innovation. Nilsson (2019) discusses that changes, interrelationships, nonlinearities, learning and innovative capacities, dynamics and paradoxes existing in supply chains can be studied with complexity theory. Nilsson and Christopher (2018) suggest that complexity theory in logistics research challenges several of the existing common assumptions in logistics and provides a dialectic perspective on the strategic dimensions of logistics management, e.g., how to work with paradoxes. Complexity perspective focuses on applying transformative perspective to study paradox.

Institutional complexity theory deals with the tensions at the institutional level and organizational level (Greenwood et al., 2011; Smith and Tracey, 2016). It depicts competing demands emerging as contradictory and oppositional (Longoni et al., 2019). Greenwood et al. (2011) describe that competing demands originate from the incompatible ideas from multiple perspectives. The concept of institutional complexity describes the situation in which organizations "confront incompatible prescriptions from multiple institutional logic" that "provide guidelines on how to interpret and function in social situations" (Greenwood et al., 2011, p.318). Institutional complexity focuses on implementing effective structures at the organization and field level to manage tensions.

The contingency theory claims that there is no best way to organize a corporation, to lead a company, or to make decisions (Fiedler, 2005; Scott and Davis, 2015). Managers select one side of the competing demands to make optimal decisions based on the internal and external environments (Lewis and Smith, 2014). Lewis and Smith (2014) 
discuss that the contingency theory seeks to resolve the paradoxes by determining when and where to focus on each strategy separately, while the PT promotes paradoxes with both strategies simultaneously. Cunha et al. (2019, p.715) conducted their work at the interface of contingency theory and PT and concluded that "a contingency theory of paradox will possibly contribute to more granular view of paradox in organizations." The assumptions, view on competing demands, response to demands, and mindset of the four theories are summarized in Appendix Table A.1.

\section{Systematic literature review (SLR) methodology}

Durach et al. (2017) argue that SLR has been applied in many fields such as medicine, but has had limited use in the SCM domain. They suggest that a six-step approach is appropriate for use in SCM. The approach that we used is shown in Fig.1. In step 1, we define the research questions. In step 2, we determine the required characteristics of the study. In step 3 we retrieve a sample of potentially relevant literature to test the approach, and in step 4 we select the applicable literature. In step 5, we conduct a within case analysis to summarize the literature and then report the results in step 6. As Durach et al. (2017) argue that biases (retrieval bias, publication bias, inclusion bias, and within-study bias) will appear if each step is not addressed carefully. We addressed each of these biases in every step of conducting the systematic literature review. 


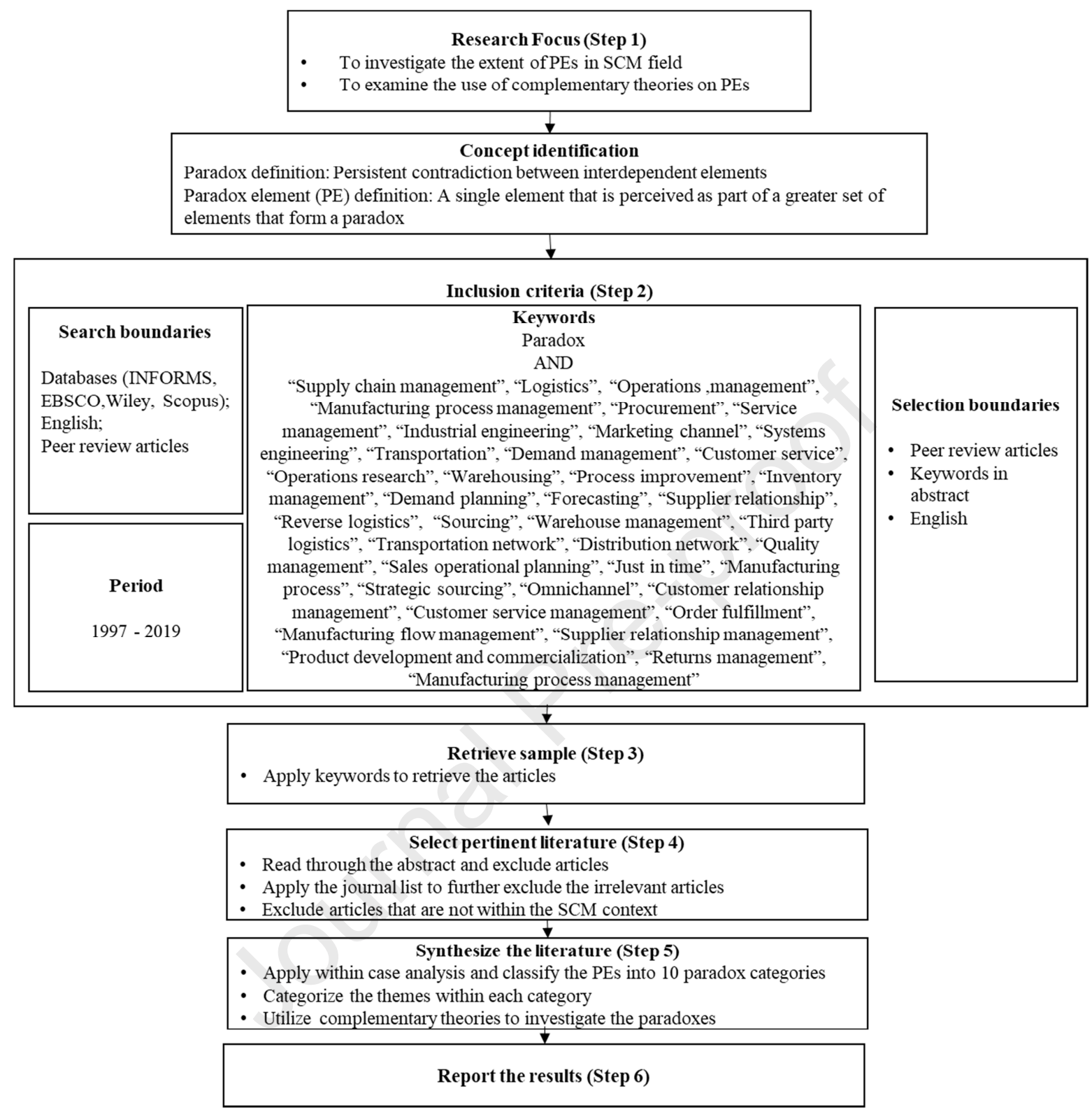

Fig. 1. Systematic Literature Review (SLR) Process

\subsection{Defining the Research Questions (Step 1)}

There are many articles in the SCM literature that deal with apparent paradoxes. However, these articles don't provide theoretical foundations, such as the use of PT in conjunction with their findings. Also, several articles discuss the paradoxes, but fall short of mentioning the specific PEs that create the events. For example, Cerruti et al. (2016) discuss a paradox in the context of purchasing that occurs between short-term relationships, such as spotbuying, and long-term strategic partnerships but don't provide insight on how to handle the conflicts. The PT and 
complimentary theories may provide a framework to suggest ways to handle paradoxes since many SCM studies that investigate the PEs, don't apply PT, and vice versa. This study first examines the extent of PEs in SCM and demonstrates one method of applying complementary theoretical approaches to investigate these PEs.

\subsection{Determining the Required Characteristics of the Study (Step 2)}

This study includes articles that range from January 1997 to October 2019. Due to the paucity of PT studies in SCM, we had to span two decades to sufficiently cover the body of knowledge, including the emergence of the idea of organizational paradox. Both qualitative and/or quantitative methodologies are included because both methods benefit from SLR in SCM (Durach et al., 2017). Thomé, Scavarda, and Scavarda (2016, p.411) suggest that "at least two but preferably more than two databases or journals should be searched.” The databases employed in this study are ABI/INFORM Complete (ProQuest), Academic Search Complete (EBSCO host), Scopus (Elsevier), and Wiley Online Library. ABI/INFORM Complete (ProQuest) is the largest database including full-text of scholarly and trade journal articles in business, management, and trade. While Wiley Online Library covers a considerable number of SCM journals, Academic Search Complete (EBSCO) and Scopus (Elsevier) are the interdisciplinary databases that also capture business and management topics. As a citation database, Scopus (Elsevier) also ensures a broader diversification of studies, as it indexes several journals and vendor databases in a single location (Thomé, Scavarda, and Scavarda, 2016). Initially we searched the keywords in full article texts. However, we found that including entire text did not yield much added value, but instead, provided a large number of search results that inhibited our ability to identify relevant PEs. After reading a dozen articles, it was clear that PEs were included in the abstracts. Therefore, we only included articles whose abstracts include the word "paradox" and synonyms of "supply chain management" together. The reason we included articles that only have "paradox" in the abstract is to follow the approach in Smith and Lewis (2011) that differentiates paradoxes from dilemmas, trade-offs, and dialectics.

Therefore, we only focused on paradoxes that expressly denotes paradoxical tensions, and excluded keywords such as dialectic, trade-off, and dilemma, because they do not fully satisfy the definition of paradox which is interdependence and persistent contradiction among the PEs (Smith and Lewis, 2011). 


\subsection{Retrieving a Sample of Potentially Relevant Literature (Step 3)}

The use of multiple, large databases addresses the retrieval bias, since it reduces the chance to miss any relevant articles. We also finalized a list of SCM journals to retain the articles to sort through and excluded the studies that are not related to SCM. We first selected three SLR papers (Fabbe-Costes and Jahre, 2008; Colicchia and Strozzi, 2012; Seuring and Gold, 2012) and also used the impact factor and "citation centrality criteria" to identify relevant journals. We also assumed that if a journal publishes a literature review in SCM, then the journal can be considered relevant to the SCM domain. We therefore included relevant journals that employed SLR in SCM. Our search found 63 journals that met all of the criteria (See Appendix Table A.2). The use of the list of 63 SCM related journals, in lieu of any subjective preferred list of journals, addressed the publication bias because we included all qualified SCM journals.

Durach et al. (2017) suggest that a proper search applies a combination of search strings, which are based on research purpose, research questions and inclusion/exclusion criteria. We subjected articles in the 63 journals to a series of steps. Initially, we created a SCM domain keyword table which classifies articles based on the terms “Supply Chain Management”, "Logistics”, “Operations Management”, "Manufacturing Process Management”, “Service Management”, "Production Management”, "Industrial Engineering”, “Systems Engineering”, "Procurement", and "Marketing Channel". Later, we formed an expert panel and asked the experts to help us expand and refine the keywords list. We first consulted with five SCM scholars to help develop our SCM keyword table. We also consulted with two SCM practitioners who have 20+ years of industry experience in SCM practice. They helped us to include more relevant keywords that were not captured previously. As a final step, we consulted with subject librarians on the selection of keywords. In total, we had a list of 37 synonyms for the key phrase "supply chain management". Table 1 lists the synonyms for the keyword "supply chain management". The key phrases are ranked according to their frequency of use. 
Table 1

The expert-opinioned synonyms of supply chain management.

$$
\text { Number of times a synonym of supply chain management is indicated within parentheses }
$$

\begin{tabular}{|c|c|c|}
\hline Logistics.............................. (10) & Warehousing ............ & Process Improvement ..............(1) \\
\hline Operations Management................... (9) & Inventory Management ...................(1) & Demand Planning ......... \\
\hline Manufacturing Process Management........ (8) & Forecasting $\ldots \ldots \ldots \ldots \ldots \ldots \ldots \ldots \ldots \ldots \ldots \ldots \ldots \ldots \ldots \ldots$ & Supplier Relationship ..............(1) \\
\hline Procurement................ & Reverse Logistics ........... & Sourcing $\ldots \ldots \ldots \ldots \ldots$ \\
\hline Service Management....... & Third Party Logistics ......................(1) & Transportation Network \\
\hline Industrial Engineering......................(6) & Distribution Network .....................(1) & Quality Management ... \\
\hline Production Management.....................(6) & Sales Operational Planning ................(1) & Just in time ........... \\
\hline Marketing Channel......... & Manufacturing Processes ...................(1) & Strategic Sourcing .... \\
\hline Systems Engineering...... & Customer Relationship Management ......(1) & Omnichannel .......... \\
\hline Transportation............................... (2) & Customer Service Management ............(1) & Order Fulfillment ............. \\
\hline Demand Management.....................(2) & Manufacturing Flow Management .........(1) & Returns Management ......... \\
\hline Customer Service.......... & Supplier Relationship Management .........(1) & \\
\hline Operation Research.... & Product Development and Commercialization (1) & \\
\hline
\end{tabular}

With the combination of 37 SCM field related keywords/phrases, "Supply chain management", and "Paradox", we performed the search within the abstracts of the targeted literature. The overview of the article search and evaluation process following (Mokhtar et al., 2019) is presented in Fig. 2 and explained in the following sections.

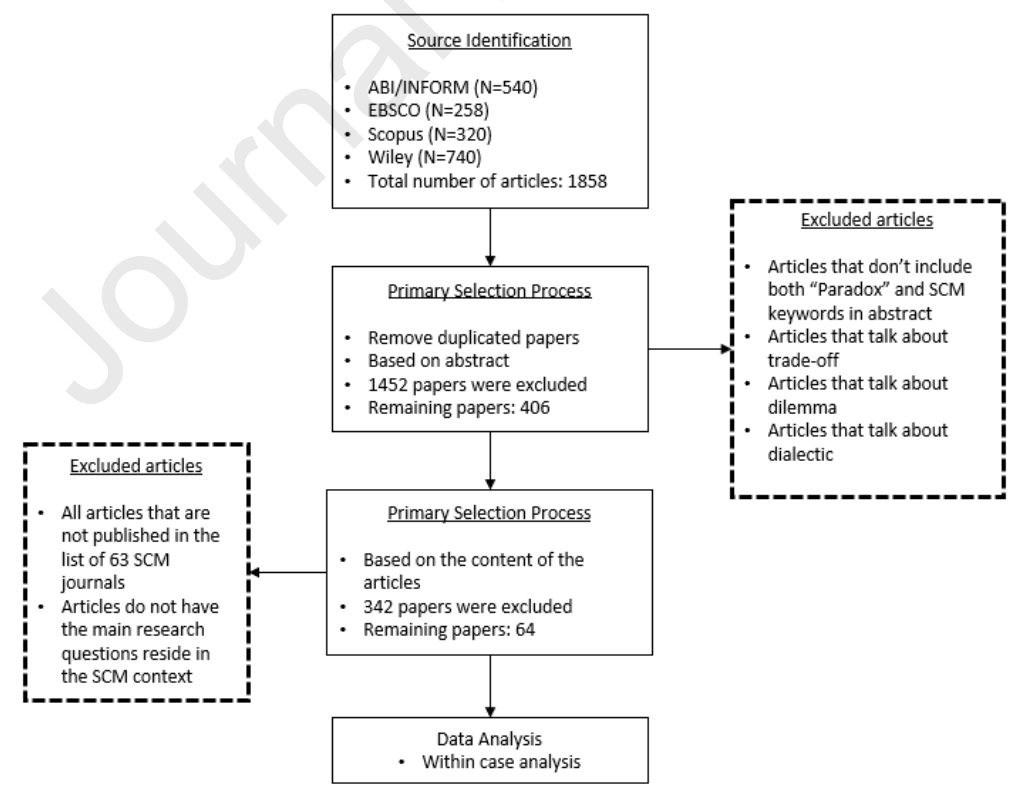

Fig. 2. Article search and evaluation process

\subsection{Selecting the Pertinent Literature (Step 4)}

In step 4, the inclusion and exclusion criteria were applied to select the articles. The initial number of articles found in each database were 540 in the ABI/INFORM Complete (ProQuest), 258 for in the Academic Search 
Complete (EBSCO host), 320 in the Scopus (Elsevier) and 740 in the Wiley Online Library. After the initial search, the combined articles totaled 1,858 . We first developed the inclusion and exclusion criteria independently, and then compared them. Developing the inclusion and exclusion criteria individually helps to address the inclusion bias, which could lead to the emergence of incorrect results (Durach et al., 2017). In summary, the inclusion criteria included articles published in 4 databases, 1997-2019, English only, and Peer reviewed. If an article mentioned both the SCM field keywords and "paradox" in the abstract, we kept the article for further analysis. Otherwise, articles that do not mention both keywords would be excluded. The number of studies that met all inclusion and exclusion criteria were 168 from ABI/INFORM; 46 from Academic Search Complete (EBSCO host); 90 articles from Scopus (Elsevier), and 102 articles from Wiley Online, totaling 406. In the final step, we applied the list of 63 journals as filters for the 406 articles. The second exclusion criterion excluded all of the articles that are not published on the journal list. The last exclusion criterion is articles where the main research question does not address a supply chain topic. This left a total of 64 articles in the literature review.

\subsection{Synthesizing the Literature (Step 5)}

We conducted a within-case analysis to extract the PEs in each article. Having multiple researchers extract the PEs individually addresses the within-study bias (Durach et al., 2017). After several rounds of classification, consensus was reached for the final list of paradoxes and related PEs. In order to validate the final list, two additional SCM scholars reviewed the results and made recommendations that improved the accuracy of the coding process. This led to the identification of 68 unique paradoxes extracted from the initial 81 paradoxes identified in the 64 articles (Appendix Table A.3). Among the 68 unique paradoxes, 65 of them are PE pairs that have two PEs. We noticed two separate paradoxes with three elements in separate articles (Choi and Eboch, 1998; Schmidt, Foerstl, and Schaltenbrand, 2017), and one paradox with four PEs (Matthews et al., 2016). During the synthesis stage, the 65 PE pairs were coded into the paradox categories of performing paradox, organizing paradox, belonging paradox, and learning paradox (Smith and Lewis, 2011). The PEs reflecting tensions between building upon and destroying the past to create a future were put into the learning paradox category ("L" in Table A.3). The PEs reflecting structuring and leading tensions were put into the organizing paradox category ("O" in Table A.3), and the PEs reflecting tensions between multiple stakeholder's goals were classified into the performing paradox category ("P" in Table A.3), and PEs reflecting tensions between identities were classified into the belonging paradox category 
("B" in Table A.3). The interconnections of the PEs in different paradox categories form the combinations of paradox category (Learning-Belonging, Learning-Organizing, Belonging-Organizing, Learning-Performing, Performing-Belonging, Performing-Organizing). The paradoxes that reflect tensions between and within different paradox categories were coded into the six combinations of paradox categories. The Cohen's Kappa on the grouping of categories is 0.88, which indicates a high intra-rater agreement rate (Cohen,1960; Boon-itt et al., 2017). The researchers then discussed any coding anomalies until consensus was reached on the coding category. The PE pairs were finally grouped into 10 paradox categories.

Lewis (2000) discussed the themes within each paradox category, and we extended these themes to develop new themes. Within each category, we color coded the emerging themes from the PEs and classified them into a theme only after reaching full consensus from the expert panel. The classification procedures went through three iterative rounds until the consensus was reached. Three themes emerged in the learning paradox category: old, new, and present. These themes reflect the time nature of the learning PEs. In the organizing paradox category, we classified organizing PEs into five themes: collaboration, efficiency and control, exploration, competition, and others. These themes reflect the structuring and leading nature of the PEs. In the belonging paradox category, we classified belonging PEs under two themes: single entity and multiple entities. These themes reflect the identity nature of the PEs. And lastly, in the performing paradox category, we classified performing PEs under seven themes: specific, service, cost, forecast, sustainability, overall, and investment. These themes reflect the nature of stakeholders' competing goals.

The panel further analyzed the paradoxes under the complementary use of contingency theory, institutional complexity theory, and complexity perspective. The experts individually visited each of the alternative theoretical approaches and coded the paradoxes into contingency theory, institutional complexity theory, and complexity perspective as paradoxes are perceived to fall into the scope of the theories. When the coding process was done, the panel discussed the results until consensus was reached on any disagreements with the coding.

\subsection{Reporting the Results (Step 6)}

Journal of Supply Chain Management has largest number of paradoxes with seven PE pairs and a paradox with four PEs. The Decision Sciences journal has seven paradoxes with PE pairs. Sustainability journal, Production and Operations Management journal, and International Journal of Operations and Production Management each has six 
paradoxes with PE pairs. Omega: an international journal of management science and Journal of Operations

Management each has five paradoxes with PE pairs. International Journal of Logistics Research and Application has four PE pairs. Transportation research part E and International Journal of Physical Distribution and Logistics Management each has three PE pairs.

Fig. 3 presents the number of articles investigating PEs in each year. It shows that the usage of the PEs in SCM has increased between years 1997 and 2019, with the largest increase beginning in 2014. This increase in numbers has also been steady over the years.

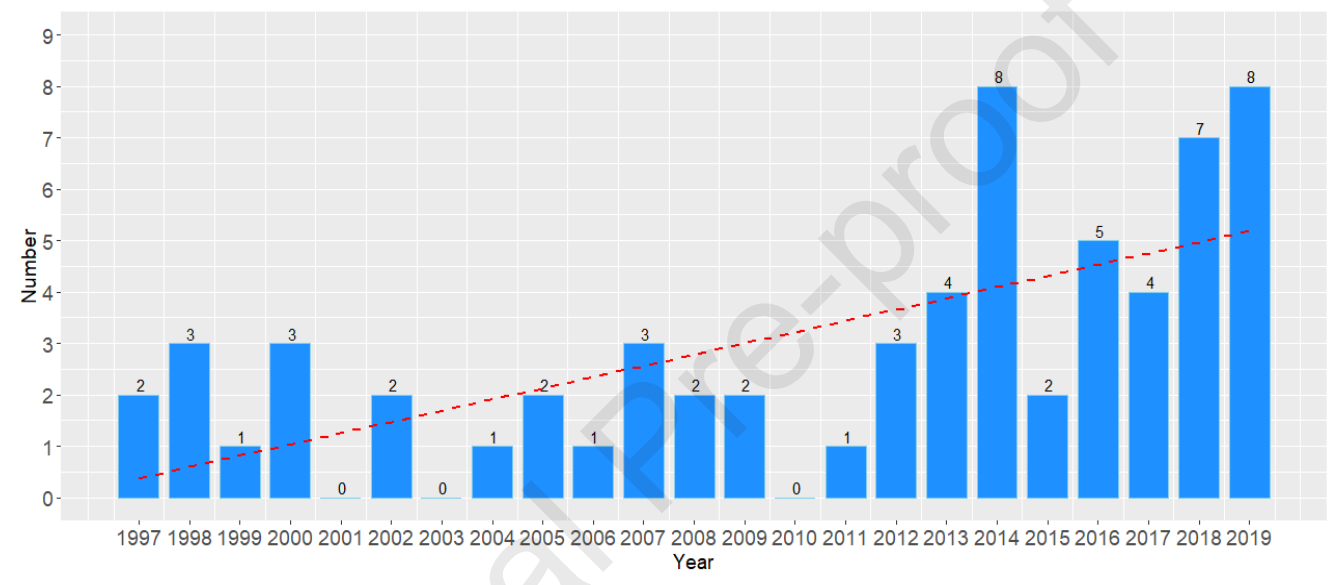

Fig. 3. Articles investigating paradoxes over the years of $1997-2019$

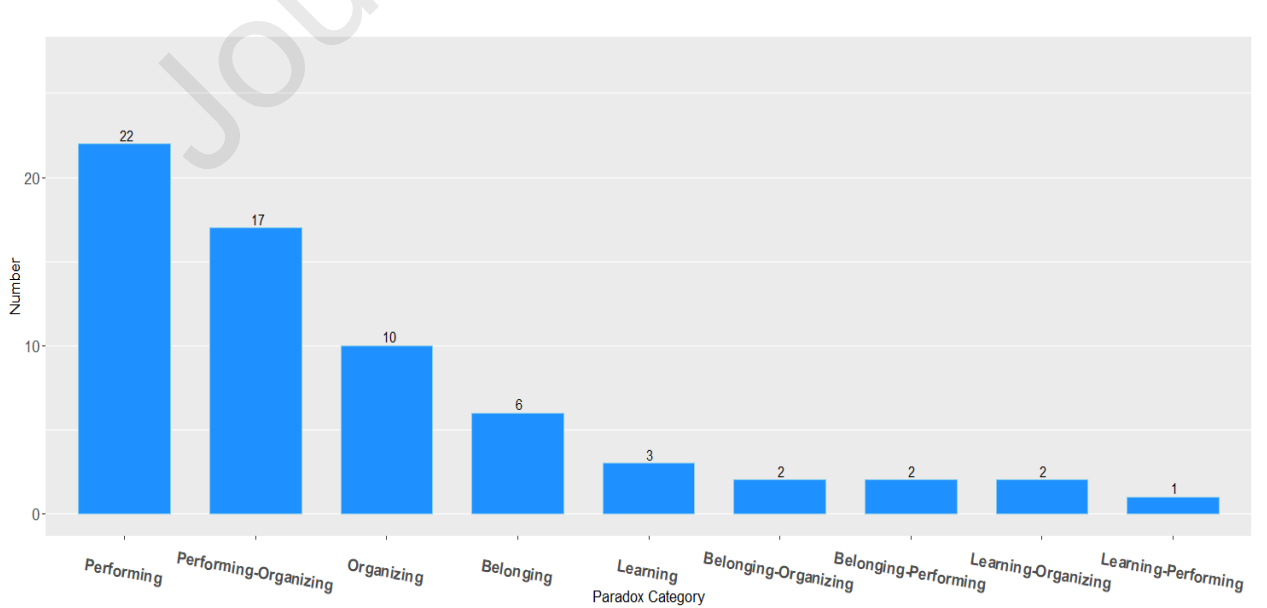

Fig. 4. Number of unique paradoxes under each paradox category

Fig. 4 is a pareto analysis of the number of unique PE pairs $(n=65)$ under each paradox category. The performing paradox category has the largest number of PE pairs which is followed by the intersection of performing-organizing 
paradox category, and then by the organizing paradox category. We did not find any PE pairs to group into the learning-belonging paradox category. Fig. 5 shows the linkages between PEs within and across the paradox categories. Complementary to fig. 4, fig. 5 shows how the PE pairs are plotted and linked among the four paradox categories. It shows that most of the PEs connect with others in the same paradox category. Some of the PEs are linked across different categories, forming combinations of paradox categories. For example, performing and organizing paradoxes have the largest number of links, creating the performing-organizing category and relevant PE pairs.

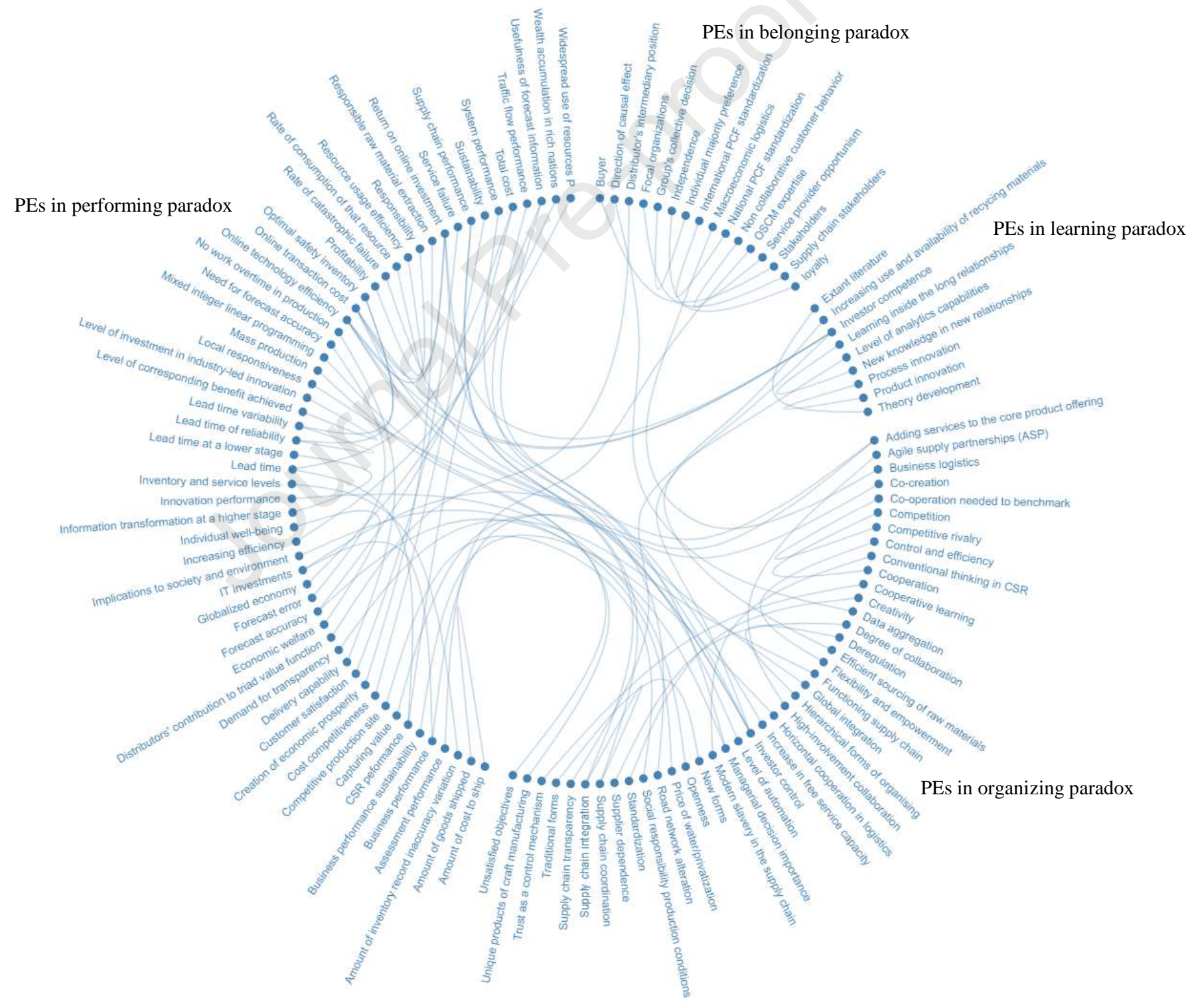


Fig. 5. PE pairs in the paradox categories

During this process, the study identified some well-known paradoxes that apply to SCM, such as Braess paradox in transportation, where an increase in the number of routes between two or more points, i.e. A and B, increases travel time, which is counter-intuitive. It is created because given multiple routes, travelers will all choose the shortest route, instead of an alternative, which increases congestion and increases travel time. (Yang, 1997; Masuda and Whang, 2002; Yang and Chen, 2009; Rapoport, Gisches, and Mak, 2014; Zhao, Fu, and Wang, 2014; Mak et al., 2018; D’Ambrosio, Gentili, and Cerulli, 2019; Ma et al., 2019). Rapoport, Gisches, and Mak (2014) mention that even though Braess paradox, like others, occurs on theoretical level, there is less empirical evidence supporting its existence, and most are highly contextual. Studies also try to identify the causes of Braess paradox, such as elastic traffic demand (Zhao et al., 2014) and route choice behavior (Rapoport et al., 2014). Baress paradox exists in other SCM contexts, such as airway network (Ma et al., 2019). Another famous SCM paradox is more-for-less paradox (Adlakha and Kowalski, 1998; Adlakha and Kowalski, 2000; Adlakha et al., 2007). The more-for-less paradox applies to freight, describing when it is possible to ship more total goods for less (or equal) total cost, while shipping the same amount or more from each origin and to each destination, while keeping all the shipping costs non-negative (Adlakha and Kowalski, 1998; Adlakha and Kowalski, 2000; Adlakha et al., 2007). Understanding this more-forless paradox is helpful to a manager in deciding which warehouse or plant capacities are to be increased and which markets should be sought (Adlakha and Kowalski, 1998). We also identified a lead-time paradox (Li et al., 2005), which describes the fact that the information transformation in SCM at higher stages decreases with the increase of lead-time at a lower stage. Another paradox related to transportation is Downs-Thomson paradox in channel management (Yin and George Zhang, 2019), which describes that under the customer's self-interest choice for the two service channels, an increase in the free service capacity (free highway) may have a negative impact on the overall system performance owing to its effects on the scale economies of the toll service system (toll highway). These paradoxes demonstrate existing linkages with PT by providing a rich research stream for future SCM studies.

Table 2 shows the usage of method and theory in the articles identified. Among the 64 articles, 40 articles apply quantitative design, while only 9 articles apply qualitative design. 13 articles are either conceptual papers or literature reviews. Only 2 articles apply mixed methods. Among the 64 articles, 7 articles apply PT; 2 articles apply institutional theory and 2 articles apply resource-based view. The other theories were utilized once among the identified article pool. We also found 24 articles that don't use any theories. 
Table 2

Theories and methods used in the articles \& number of related paradoxes.

\begin{tabular}{llcccc}
\hline & & No. of articles & Percentages & No. of unique paradox & Percentage \\
\hline \multirow{2}{*}{ Methods } & Quantitative design & 40 & $62.50 \%$ & 31 & $45.59 \%$ \\
& Qualitative design & 9 & $14.06 \%$ & 17 & $25.00 \%$ \\
& Mixed methods & 2 & $3.13 \%$ & 2 & $2.94 \%$ \\
& Conceptual papers \& literature reviews & 13 & $20.31 \%$ & 18 & $26.47 \%$ \\
\multirow{2}{*}{ Theories } & Paradox theory & 7 & $10.94 \%$ & $22.06 \%$ \\
& Institution theory & 2 & $3.13 \%$ & 2 & $2.94 \%$ \\
& Resource based view & 2 & $3.13 \%$ & 2 & $2.94 \%$ \\
& Others* & 29 & $45.31 \%$ & 26 & $38.24 \%$ \\
\hline
\end{tabular}

* Include well-known paradoxes (Braess paradox, More-for-less paradox, Lead time paradox, and Downs Thomas paradox).

Table 3 lists the themes that emerged in each paradox category with 7 themes in performing paradox, 5 themes in organizing paradox, 3 themes in learning paradox, 2 themes in belonging paradox. It also shows the PEs under each theme. The PEs under the themes are single elements from each paradox pair. Since performing paradox has the largest number of themes and PEs, performing paradox has a large group of PEs. The second largest group is organizing paradox followed by belonging paradox and then learning paradox.

Table 3

PEs and themes under paradox categories

\begin{tabular}{|c|c|c|c|c|c|c|}
\hline \multirow[b]{2}{*}{ Cost } & \multirow[b]{2}{*}{ Forecast } & \multirow[b]{2}{*}{ Investment } & \multicolumn{4}{|l|}{ Performing Paradox } \\
\hline & & & Service & Specific & Sustainability & Overall \\
\hline $\begin{array}{l}\text { Cost competitiveness } \\
\text { (Xiao et al., 2019); } \\
\text { Compentitive } \\
\text { production site } \\
\text { (Brix-Asala et al., } \\
\text { 2018); } \\
\text { Mass production } \\
\text { (Duray et al., 2000); } \\
\text { Total cost (Sandberg, } \\
\text { 2017); } \\
\text { Cost of goods } \\
\text { shipped (Adlakha } \\
\text { and Kowalski, 1998; } \\
\text { Adlakha and } \\
\text { Kowallki, 2000; } \\
\text { Adlakha et al., 2007) }\end{array}$ & $\begin{array}{l}\text { Need for forecast accuracy } \\
\text { (Wacker and Lummus, } \\
2002) ; \\
\text { Forecast error (Wacker and } \\
\text { Lummus, 2002); } \\
\text { Forecast accuracy (Wacker } \\
\text { and Lummus, 2002) }\end{array}$ & $\begin{array}{l}\text { Return on online } \\
\text { investment (Looney et } \\
\text { al., 2006); } \\
\text { IT investments (Pereira, } \\
\text { 2014; Kim et al., 2005; } \\
\text { Agarwal and Prasad, } \\
\text { 1997) }\end{array}$ & $\begin{array}{l}\text { Service failure (Koufteros et } \\
\text { al., 2014; Sousa and Voss, } \\
\text { 2009); } \\
\text { Customer satisfaction } \\
\text { (Koufteros et al., 2014; Sousa } \\
\text { and Voss, 2009); } \\
\text { Inventory and service levels } \\
\text { (Kull et al., 2013); } \\
\text { Delivery capacity (Brix- } \\
\text { Asala et al., 2018); } \\
\text { Lead time variability } \\
\text { (Tyworth, 2018); } \\
\text { Lead time reliability } \\
\text { (Tyworth and Saldanha, } \\
\text { 2014); } \\
\text { Lead time at a lower stage (Li } \\
\text { et al., 2005); } \\
\text { Lead time (Sandberg, 2017); } \\
\text { Local responsiveness (Kolk, } \\
\text { 2012); } \\
\text { Amount of inventory record } \\
\text { inaccuracy variation (Kull et } \\
\text { al., 2013); } \\
\text { Amount of goods shipped } \\
\text { (Adlakha and Kowalski, } \\
\text { 1998; Adlakha and Kowalski, } \\
\text { 2000; } \\
\text { Adlakha et al., 2007) }\end{array}$ & $\begin{array}{l}\text { Distributors' contribution } \\
\text { to triad value function } \\
\text { (Vedel, 2016); } \\
\text { Wealth accumulatio in } \\
\text { rich nation (Coscieme et } \\
\text { al., 2019); } \\
\text { Level of corresponding } \\
\text { benefit achieved (Storer et } \\
\text { al., 2014); } \\
\text { Information } \\
\text { transformation at a higher } \\
\text { stage (Li et al., 2005); } \\
\text { Innovation performance } \\
\text { (Stefan and Bengtsson, } \\
\text { 2017); } \\
\text { MILP (Sarkis and Semple, } \\
\text { 1999); } \\
\text { Demand for transparency } \\
\text { (Brix-Asala et al., 2018); } \\
\text { Online technology } \\
\text { efficiency (Looney et al., } \\
\text { 2006); (1) } \\
\text { Usefulness of forecast } \\
\text { information (Wacker and } \\
\text { Lummus, 2002); } \\
\text { Traffic flow performance } \\
\text { (Masuda and Whang, } \\
\text { 2002; Yang and Chen, } \\
\text { 2009; Rapoport, Gisches, } \\
\text { and Mak, 2014; Zhao, Fu, } \\
\text { and Wang, 2014; Mak et }\end{array}$ & $\begin{array}{l}\text { Sustainability (Xiao et } \\
\text { al., 2019); } \\
\text { Responsible raw } \\
\text { material extraction } \\
\text { (Brix-Asala et al., } \\
\text { 2018); } \\
\text { Widespread use of } \\
\text { resource (Coscieme et } \\
\text { al., 2019); } \\
\text { Responsibility (Kolk, } \\
\text { 2012); } \\
\text { Rate of consumption of } \\
\text { resource (Klumpp, } \\
\text { 2016); } \\
\text { Individual well-being } \\
\text { (Coscieme et al., 2019); } \\
\text { Rate of catastrophic } \\
\text { failure (Upton and } \\
\text { McAfee, } \\
\text { Implicas); } \\
\text { (Muralions to society } \\
\text { Petruzizi, 2015); } \\
\text { Increasing efficiency } \\
\text { (Coscieme et al., 2019); } \\
\text { Resource usage of } \\
\text { efficiency (Klumpp, } \\
\text { 2016); } \\
\text { Economic welfare } \\
\text { (Coscieme et al., 2019) }\end{array}$ & $\begin{array}{l}\text { No work overtime in } \\
\text { production (Brix-Asala et } \\
\text { al., 2018); } \\
\text { Profitability (Kolk, 2012); } \\
\text { Globalization economy } \\
\text { (Coscieme et al., 2019); } \\
\text { Capturing value (Niesten } \\
\text { and Stefan, 2019); } \\
\text { Business performance } \\
\text { sustainability (Basso et } \\
\text { al., 2019); } \\
\text { System performance (Yin } \\
\text { and George Zhang, 2019); } \\
\text { Creation of ceonomic } \\
\text { prosperity (Brix-Asala et } \\
\text { al., 2018); } \\
\text { Assessment performance } \\
\text { (Tazelaar and Snijders, } \\
\text { 2013); } \\
\text { CSR performance } \\
\text { (Sandberg, 2017); } \\
\text { Supply chain performance } \\
\text { (Chiadamrong and } \\
\text { Wajcharapornjinda, 2012; } \\
\text { "Henry" Jin, Fawcett, and } \\
\text { Fawcett, 2013); } \\
\text { Business performance } \\
\text { (Pereira, 2014; Kim et al., } \\
\text { 2005; } \\
\text { Agarwal and Prasad, } \\
\text { 1997; Kastalli and Van }\end{array}$ \\
\hline
\end{tabular}




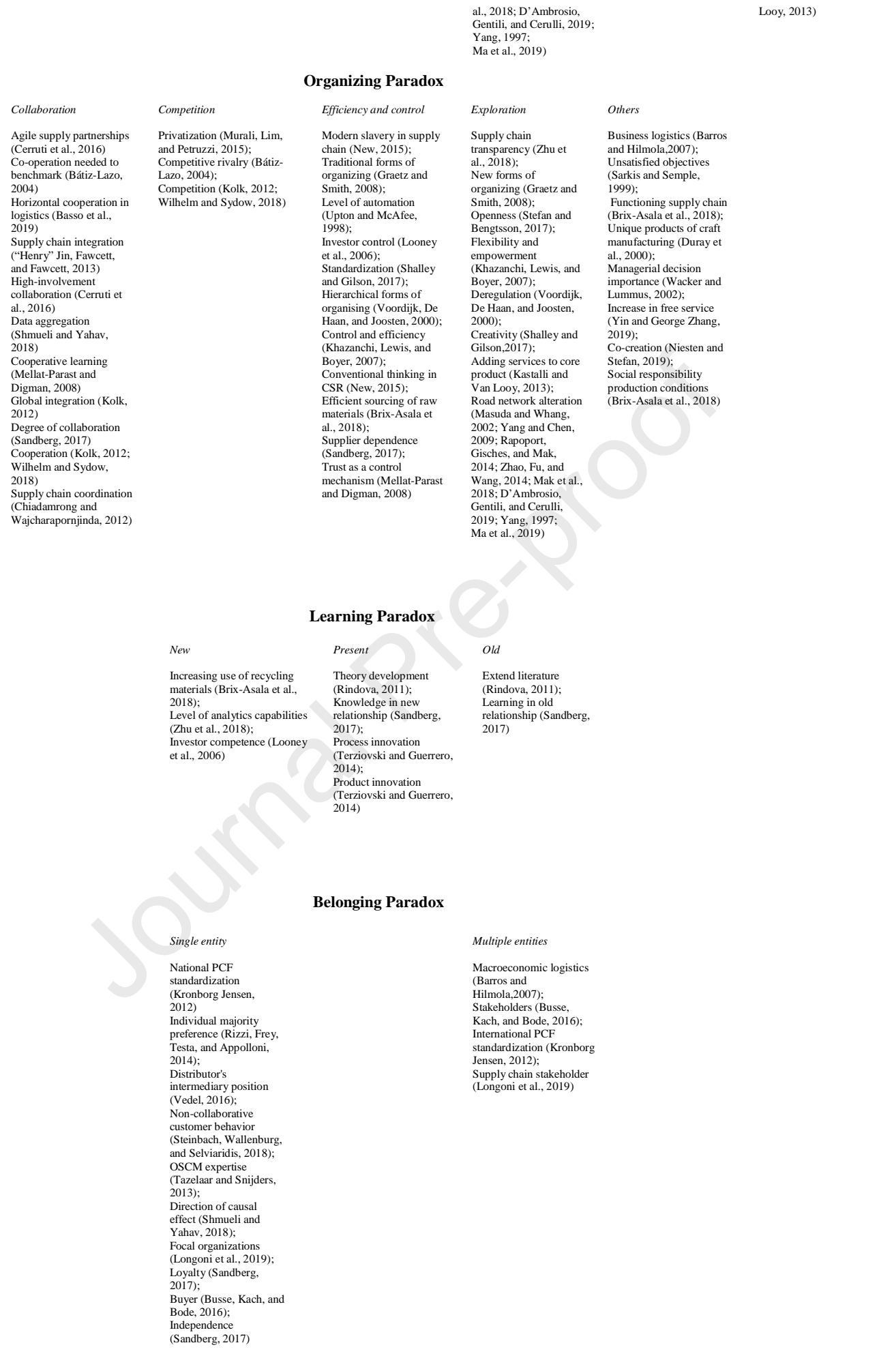


Fig.6 shows the percentage of each paradox categories that can be studied with an alternative theoretical lens. The 65 paradox pairs can be investigated under the PT. While PT can be applied to investigate the 65 paradox pairs, this figure shows the distribution of these elements that can be investigated by each of the other three theories.

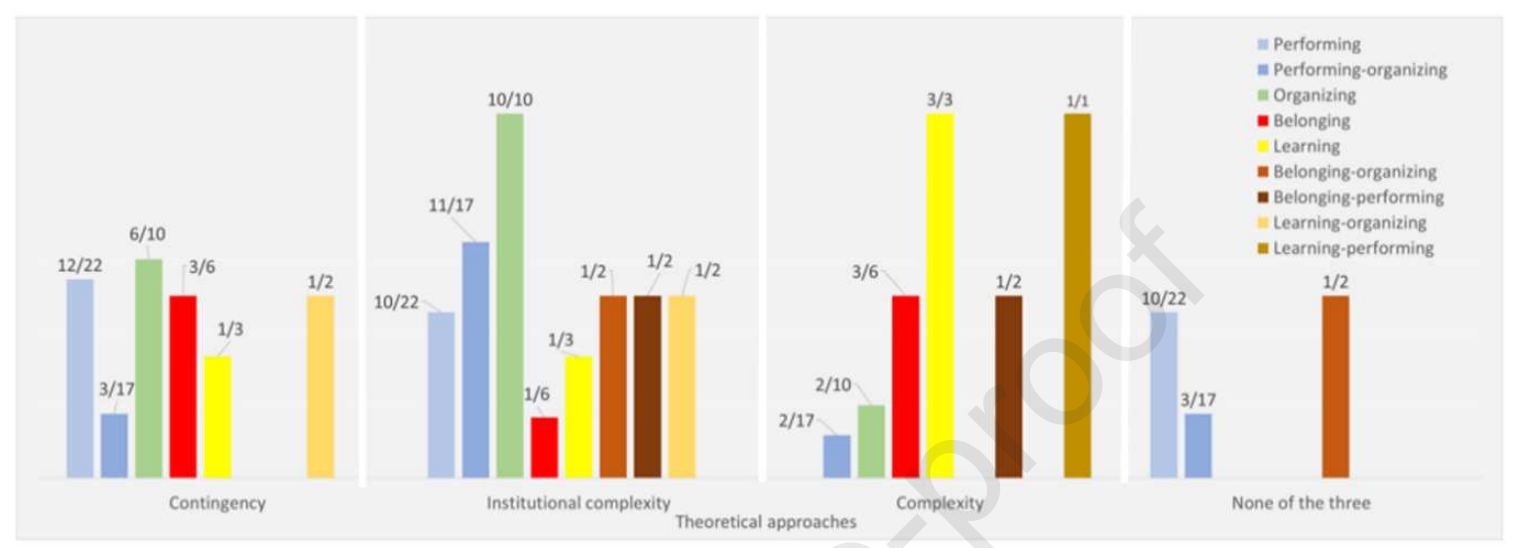

Applicability ratio: $A / B$; where $A$ is the number of paradoxes in the category shown that can be investigated by the given theoretical approach, and $B$ is the total number of paradoxes within each category shown

Fig. 6. Applicability of different theoretical approaches per paradox category

\section{Discussion}

This literature review identifies seven articles that apply PT. Among the seven articles, four articles discuss sustainability issues in SCM. Xiao et al. (2019) investigate the paradox between cost competitiveness and sustainability. Brix-Asla et al. (2018) research the social-economic and environmental performance. Sandberg (2017) explicates PEs in sustainability issues. Matthews et al. (2016) further the discussion between different levels of sustainability and among the different types of theory being produced to the challenges of sustainability. Two articles (Niesten and Stefan, 2019; Wilhelm and Sydow, 2018) incorporate co-creation and value capture and cooperation and competition. One article (Longoni et al., 2019) applies both institutional theory and PT to investigate the competing demands between business logistics and macroeconomic logistics, signaling the necessity and benefits of combination of PT and other theoretical approaches to investigate paradoxes.

\subsection{Complementary theories}

In addition to PT, we employed contingency theory, institutional complexity theory, and complexity perspective as the theoretical approaches to make sense of the PEs identified in this literature review. In our analyses of the 
potential application of a complementary theoretical lens, we find that more than half of the organizing paradoxes and of performing paradoxes could be investigated by the contingency theory. Contingency theory describes dichotomous decisions under A or B selection and could be applied to investigate paradoxes identified under the organizing paradox and performing paradox categories (Fiedler, 2005; Scott and Davis, 2015; Lewis and Smith, 2014; Kalchschmidt, 2012). The organizing paradox describes tensions from a complex system (both A and B, then B and A, etc. until a preferred state is reached), while the performing paradox comes from the tensions of different stakeholder's goals (Smith and Lewis, 2011). Both the complex system and the performance tensions can change based on the internal and external conditions, which is the core of contingency theory. Contingency theory can help inform the handling of tensions based on the change of the environments.

Institutional complexity theory could be applied to most of the paradox categories. Among the nine paradox categories we identified in this literature review, organizing paradoxes and performing-organizing paradoxes can be investigated in combination of PT and institutional complexity theory. While misaligned logistics are also sources of organizing paradoxes because they act as complex systems, the institutional complexity theory also depicts the competing demands emerging from misaligned logistics as contradictory and oppositional (Longoni et al., 2019). Performing-organizing paradoxes indicate that organizations seek stable routines while at the same time enabling dynamic outcomes (Smith and Lewis, 2011), and this paradox also accentuates the use of institutional complexity theory. Half of the paradoxes under belonging-organizing, belonging-performing, and learning-organizing paradox categories, as well as all of organizing paradoxes can be investigated by institutional complexity theory.

Half of the belonging and belonging-performing paradoxes can be investigated under the complexity lens. All of the learning and learning-performing paradoxes can be investigated under the complexity lens. The complexity perspective (Nilsson and Christopher, 2018) argues for developing a transformative mindset that views competing demands as normal. Our findings indicate that paradoxes under belonging, learning, belonging-performing, and learning-performing paradox categories could be investigated with this theory. The learning paradox mentions the creation of new knowledge and maintenance of routine create tensions (Smith and Lewis, 2011). It is rooted in people's assumption regarding the old and new, which is where the complexity perspective becomes relevant. Complexity perspective can help develop a transformative mindset to view the competing demands between old and new as normal and develop an efficient way to handle the learning paradox. The belonging paradox investigates the 
tensions between the identity, and complexity perspective can help develop a paradox mindset to handle the belonging tensions.

We also found that nearly half of performing paradoxes, a small portion of performing-organizing paradoxes, and half of belonging-organizing paradoxes could only be investigated under PT. The examples of these paradoxes are under performing paradox (customer satisfaction and service failure in Koufteros et al., 2014), under performing-organizing paradox (Braess paradox in Mak et al., 2018; D’Ambrosio, Gentili, and Cerulli, 2019), and under belonging-organizing paradox (direction of casual effect and data aggregation in Shmueli and Yahav, 2018). All of these paradoxes are perceived by some to be impractical and primarily theoretical. However, since these paradoxes are persistently contradicting and interdependent in the article settings, they could potentially be investigated with the PT.

\subsection{Emergence of the themes}

The performing paradox includes seven themes: service, overall, investment, forecast, cost, sustainability, and specific. The service theme groups the PEs, which have a service outcome to the supply chain customers, such as optimal safety inventory (Tyworth, 2018) and service failure (Koufteros et al., 2014; Sousa and Voss, 2009). The overall theme is relevant to the supply chain end goals, such as system performance (Yin and George Zhang, 2019) and supply chain performance (Chiadamrong and Wajcharapornjinda, 2012). The investment theme is grouped based on paradox of investment return. There are studies (Looney et al., 2006; Pereira, 2014) that talk about the paradox between advanced investment technology and the return on investment or performance. The investment theme captures the paradoxical investment performance. The forecast theme groups the PEs relevant to forecast accuracy (Wacker and Lummus, 2002). The cost theme groups the PEs on cost of goods sold and cost competitiveness. This theme reflects the cost characteristic in supply chain, such as the cost of goods sold (Adlakha and Kowalski, 2000) and global sourcing cost (Sandberg, 2007). The sustainability theme reflects the sustainable issues in supply chain management (sustainability and Responsible raw material extraction, Brix-Asala et al., 2018). The specific theme includes the PEs with different but of specific nature, such as traffic flow performance from Braess paradox (Mak et al., 2018; D’Ambrosio, Gentili, and Cerulli, 2019); online technology efficiency (Looney et al., 2006); usefulness of forecast information (Wacker and Lummus, 2002). 
The organizing paradox includes five themes: collaboration, competition, control and efficiency, exploration, and others. The collaboration theme includes the PEs that capture the collaborative nature. On one hand, supply chain collaboration has potential benefit on cost reduction. On the other, agile supply chain partnership is helpful on retaining new resources (Cerruti et al., 2016). The competition theme includes the PEs that reflect the competitive nature in supply chain. The control and efficiency theme includes the PEs that are relevant to trust as a control mechanism (Mellat-Parast and Digman, 2008) and standardization as a form of control (Shalley and Gilson, 2017). This theme focuses on different forms of control and increasing efficiency with these different control forms. The exploration theme groups the innovative and explorative PEs, such as alternation to a road network (Mak et al., 2018; D'Ambrosio, Gentili, and Cerulli, 2019), openness (Stefan and Bengtsson, 2017), and creativity (Shalley and Gilson, 2017). The others theme groups all the PEs that don't fall into other themes within organization paradox.

The learning paradox has three themes: new, old, and present. Learning paradox originates from the efforts to adjust, renew, change, and innovate foster tensions between building upon and destroying the past to create the future (Smith and Lewis 2011, 383). As Lewis (2000, p.766) discusses: “A key source of learning paradoxes is tension between old and new - a struggle between the comfort of the past and the uncertainty of the future". The old theme reflects the nature of learning in the past or old relationship (Rindova, 2011; Sandberg, 2017). Literature on learning paradox (Rindova, 2011; Sandberg, 2017) mentions that learning can happen simultaneously in old relationship and new relationship, which foster a paradox on managing old and new relationships and knowledge. The new theme reflects the nature of developing new things, such as theory development (Rindova, 2011) and innovation (Terziovski and Guerrero, 2014). This new theme is opposite to the old theme. The present theme includes the PEs that don't belong either to 'old' or 'new' theme but that are relevant to learning, such as level of analytics capabilities (Zhu et al., 2018), increasing use and availability of recycling materials (Brix-Asala et al., 2018), and investor competence (Looney et al., 2006).

There are two themes under the belonging paradox: single entity theme and multiple entities theme. The belonging paradox originates from the identity tensions between individual and collective and between competing values, roles, and memberships (Smith and Lewis, 2011, p.383). The single entity theme is created based on the individual group while the multiple entities theme is created based on collective group. Therefore, single entity theme includes PEs focusing on single (individual) actor, such as National PCF standardization (Kronborg Jensen, 
2012) and individual preference (Rizzi, et al., 2014). Multiple entities theme focuses on plural actors, such as

Group's collective decision (Rizzi, et al., 2014) and international PCF standardization (Kronborg Jensen, 2012).

\subsection{Paradoxes with three and four PEs}

Our SLR also came across three studies that offered unique PE sets. PE set in Choi and Eboch (1998)'s Journal of Operations Management paper was formed via 3 PEs and this TQM study's results explicated paradoxical relations among TQM practices, plant performance, and customer satisfaction. The relationship among these three variables is nested within each other (Keller and Sadler-Smith, 2019). Published in Journal of Supply Chain Management, Schmidt, Foerstl, and Schaltenbrand (2017) presented a tripartite relationship between green supply chain management practices, SCP and economic performance and termed it Supply Chain Position Paradox. These three PEs together provide a road map to study the green supply chain management. Another Journal of Supply Chain Management paper, Matthews et al. (2016) presented 4 PEs within a PE set by looking into paradoxical tensions among different levels of analysis: encompassing individuals, the organization, interorganizational networks, and macroenvironmental levels. These four elements are also nested within each other. The PEs in these three articles provide a hint to refine the PT, which currently focuses on tensions between only two PEs.

\subsection{Sustainability tensions}

From the results, we noticed repeatedly that there is a perceived paradox between sustainability and business performance/economic goals. SCM scholars seem to have combined the environmental and social issues under a single PE while designating a standalone PE for the economic aspect. There are similarities between this perception and the one that is prevalent among layman which is tied to the expression, 'time is money', related to project management. Whereas time is not money and it is well understood, for instance the conventional management practices force many practitioners to fold time onto cost so a trade-off can be setup between cost and scope.

Following a similar logic, when sustainability components are being considered, even in scholarly works, social and environmental dimensions seem to be lumped together so a duality is formed in conjunction with the use of economic dimension. Such actions might ultimately be reducing the complexity of decision-making process and therefore managers can perhaps constrain the cognitive workload under two PEs and then perform optimization/reconciliatory tasks. 


\subsection{Shifting paradigm}

The introduction of PT into the SCM paves new paths for future research investigating the paradoxes. In this literature review, we identified studies that investigate paradoxes. However, most of these studies only focused on describing the paradoxes. Even though there are a few studies that explicitly applied PT to investigate the paradoxes, PT is not a theoretical lens mainly applied in SCM. We found that most of conflicting demands can be investigated under PT. Unlike the belief that conflicting demands are adversarial, a new perspective gradually shifts to a view that these conflicting demands are interconnected and can be studied and handled. For example, the tensions between competitiveness and sustainability can be alleviated by fostering "paradoxical sensemaking" among managers (Xiao et al., 2019). We can argue that instead of using adversarial sensemaking on the conflicting demands, future SCM scholars and practitioners can benefit from the cultivation of paradoxical sensemaking, learning to accept and embrace the tensions. Though it is not easy to scrap an old mindset, continuous iterations could enable a paradigm shift toward development of a new mindset. As Lewis and Smith (2014) mention, PT is relatively new to management, but its early advocates drew from a rich history, grounded in well-established philosophies. PT lens could eventually change SCM scholars' and practitioners' perspectives to view and handle paradoxes.

\subsection{Managerial insights}

Managers, who need to balance competing aims in supply chains, such as local responsiveness and global integration (Kolk, 2012), and agile supply chain and high involvement collaboration (Cerruti et al., 2016), etc., directly deal with paradoxes. Luscher and Lewis (2008) discuss that how actors react to the competing demands will trigger various consequences through virtuous or vicious cycles, and these can impact either negatively or positively on actors themselves and/or others in their organization. Smith and Lewis (2011) further discuss that the cognitive complexity to accept the interrelated relationship of underlying tensions, and an emotional equanimity to reduce anxiety and fear spurred by inconsistencies, lays the vital groundwork for virtuous cycles, which lead to sustainability - short-term excellence fueling long-term success. Managers can critically examine the assumptions of PT and view these competing aims potentially unifiable, instead of using strictly adversarial ways to deal with them. They can embrace the competing aims and treat them as an opportunity to realize synergies and to grow. In doing so, the list of PEs can help managers to recognize these competing aims, and could possibly serve as a template for 
managers to identify potential PEs in their operational activities. Only when managers realize the existence of the PEs can they start to apply PT lens to study, embrace, and alleviate them. For instance, acknowledging the paradox, those managers who consider long-term collaborative relationships for company learning and development, may be reluctant to invest in new supplier relationships that could serve as an enabler for improved learning (Sandberg, 2017). Managers can apply the PT lens to view these PEs as contradictory and unified and then proceed to develop a sourcing strategy that utilizes the learning from the existing well-functioning relationships while ensuring the expanded thinking from new relationships (Sandberg, 2017). In essence, managers would be venturing beyond the traditional trade-off approach and adopting paradoxical sensemaking to explore alternative pathways. As managers start to view these tensions in a paradoxical sensemaking way, they will feel less obligated to resort to adversarial sensemaking to resolve the tensions (Smith \& Lewis, 2011; Xiao et al., 2019). Instead, realizing the interconnections between these tensions, they will find innovative solutions to alleviate them, and eventually identify new possibilities.

\section{Conclusions}

This study summarizes and classifies the PEs in SCM via the help of SLR methodology. With the time span of more than 20 years and 4 databases, we discovered a comprehensive list of PEs in SCM literature. We grouped the PEs into the extant paradox categories (Smith and Lewis, 2011) and classified them under emerging themes within each category. In accomplishing this, we offer guidance to scholars and practitioners with the inventory of the paradox categories and themes in order to provide guidance in discovering and explaining phenomenon in SCM that can lead to improved management. The need for a SLR of PEs in SCM exists due to several reasons. First, there is lack of a comprehensive list for PEs in SCM domain. Based on PT, we identify and summarize the PEs in SCM in a list so an initial assessment of the state of PE usage can be offered for use by scholars and practitioners. The list also offers a path to further extend PT into SCM while informing back the PT for its refinement. In other words, we hope to contribute to both, centripetal forces that "buffer the existing boundaries" and the centrifugal forces that "foster boundary spanning" in PT's development (Schad et al., 2019). Second, recognizing PEs is the first step to handle these related paradoxes. Handling PEs simultaneously and successfully through the creation of "cyclical responses to paradoxical tensions enable sustainability - peak performance in the present that enables success in the future" (Smith and Lewis, 2011, p.382). Third, we address the possibilities of complementarily using PT, contingency 
theory, institutional complexity theory, and complexity perspective to investigate the paradoxes and PEs identified in this study. As more and more competing demands arise during management of supply networks, there will be an increasing need to understand and even leverage these competing demands. This study provides a foundation of using complementary theoretical approaches to make sense of and further investigate paradoxes.

\section{Limitations and Future Research}

The main purpose of our research study was to search, collect, and then present the PEs in SCM literature so that they can lead to improved paradox management for practitioners and greater parsimony in classifying PEs. However, our SLR study is not without its limitations. First, the articles that were eliminated in Step 4 of our SLR that are 'talking about paradoxes and supply chains' could be included to gain possible peripheral insights in lieu of assuming them on the fringes. It will be interesting to compare and contrast the similarities and differences between PEs inside and outside SCM. Second, even though mostly captured under the core PEs of 'exploitation and exploration', including ambidextrous relationships that are examined in SCM research could further enrich our study. Third, the trade-offs in SCM could be searched, collected, and then presented along with our findings in another study to draw a broader picture of the above arguments.

The future of paradox studies in supply chain is promising. We find that the trend of the occurrence of PEs is increasing. This uptick of PEs may be related to ever-increasing business complexity and globalized organization in supply chain networks. Especially as firms increasingly establish global and complex network structures, more tensions appear and more identifiable PEs surface (Sandberg, 2017; Xiao et al., 2018). The increasing occurrences of paradoxes also indicate that there is a need to handle and manage them. One of the efforts researchers can contribute to the field is to provide a theoretical guide to inform the management of these paradoxes.

Four of seven articles applying paradox lens deal with sustainability, demonstrating that sustainability research benefits the most from PT. Varying perspectives of sustainability will benefit from using the paradox lens in different degrees and therefore future SCM research in sustainability could increase application of the paradox lens. While the paradox between competition and cooperation and the paradox between co-creation and value capture receive not as much attention as sustainability, these two are also ideal areas to apply PT.

Our results show that performing paradox and performing-organizing paradox categories have the most dominant paradox themes. Future studies can focus to investigate these two paradox categories in order to extract 
more insights. Our study also provides different themes for PEs under each paradox category. Future studies can focus on these themes and investigate their fit with the real-world situations. The themes provided in this SLR may help future studies to make sense of the PEs a priori.

Finally, a plausible argument can be made regarding the trade-offs. The analytical tools may not allow SCM scholars to obtain desired results when more assumptions are relaxed such that a strict trade-off is not warranted in a problem. Paradox theorists demonstrate over and over again that even if desired results may not be possible, meaningful results can be obtained and put into action by dealing with PEs simultaneously. Therefore, we wonder whether it is really the PT that needs to navigate and find inroads into SCM domain, or the SCM scholars should entertain investigating the not-so-frequently explored territories beyond trade-offs. 


\section{APPENDIX}

Table A.1

Comparison of the four theoretical approaches.

\begin{tabular}{|c|c|c|c|c|}
\hline & Paradox theory (PT) & Contingency theory & $\begin{array}{l}\text { Institutional complexity } \\
\text { theory }\end{array}$ & Complexity perspective \\
\hline Assumptions & $\begin{array}{l}\text { Competing demands are } \\
\text { inherent in organizations, } \\
\text { emerging through the act } \\
\text { of organization or through } \\
\text { relational dynamics or } \\
\text { individual sensemaking } \\
\text { Two elements existing in } \\
\text { relation to one another } \\
\text { Competing demands } \\
\text { persist over time, and } \\
\text { cannot be solved }\end{array}$ & $\begin{array}{l}\text { Organizational systems are } \\
\text { most effective when they } \\
\text { achieve alignment or fit } \\
\text { among internal elements } \\
\text { and with the external } \\
\text { environment. }\end{array}$ & $\begin{array}{l}\text { - Competing demands come } \\
\text { from the plurality of logics } \\
\text { at the field/societal level. } \\
\text { Multiple logics can co- } \\
\text { exist within an } \\
\text { organization, and they are } \\
\text { contradictory but can be } \\
\text { complementary. } \\
\text { Completing logics foster } \\
\text { challenges of external } \\
\text { legitimacy and internal } \\
\text { conflict that need to be } \\
\text { resolved. }\end{array}$ & $\begin{array}{l}\text { Competing demands consist } \\
\text { of complexity and } \\
\text { simplicity, order and } \\
\text { unorder, reductionism and } \\
\text { emergence, objectivity and } \\
\text { subjectivity, deliberate } \\
\text { design and self- } \\
\text { organization, rationality } \\
\text { and bounded rationality, } \\
\text { determinism and } \\
\text { indeterminism. }\end{array}$ \\
\hline $\begin{array}{l}\text { View on } \\
\text { competing } \\
\text { demands }\end{array}$ & $\begin{array}{l}\text { Competing demands are } \\
\text { consistent } \\
\text { contradictory and interdepend }\end{array}$ & $\begin{array}{l}\text { Competing demands are } \\
\text { simultaneous and not solvable. }\end{array}$ & $\begin{array}{l}\text { Competing demands are } \\
\text { contradictory but } \\
\text { complementary. }\end{array}$ & $\begin{array}{l}\text { Competing demands can be } \\
\text { studied under the } \\
\text { transformational perspective. }\end{array}$ \\
\hline $\begin{array}{l}\text { Response to } \\
\text { competing } \\
\text { demands }\end{array}$ & $\begin{array}{l}\text { Simultaneously address to } \\
\text { competing demands }\end{array}$ & $\begin{array}{l}\text { Discrete organizational } \\
\text { problems } \\
\text { to be solved (Smith and Lewis, } \\
2014 \text { ) }\end{array}$ & $\begin{array}{l}\text { Competing logics can be } \\
\text { managed by implementing } \\
\text { effective structures at the } \\
\text { organizational and field level. }\end{array}$ & $\begin{array}{l}\text { Change the mindset to view } \\
\text { competing demands in } \\
\text { logistics as normal and a } \\
\text { resource for supply chain } \\
\text { effectiveness }\end{array}$ \\
\hline Mindset & $\begin{array}{l}\text { Engage A and B } \\
\text { simultaneously }\end{array}$ & $\begin{array}{l}\text { Under what conditions either A } \\
\text { or B }\end{array}$ & $\begin{array}{l}\text { Implementing effective } \\
\text { infrastructure }\end{array}$ & $\begin{array}{l}\text { A transformation mindset on } \\
\text { logistics effectiveness and } \\
\text { innovation }\end{array}$ \\
\hline
\end{tabular}


Table A.2

List of the 63 SCM journals.

\begin{tabular}{|c|c|c|c|c|c|c|}
\hline Number & Journal Name & $\begin{array}{c}\text { Impact Factor } \\
\text { (Fabbe-Costes and } \\
\text { Jahre,2008) }\end{array}$ & $\begin{array}{l}\text { Citation Centrality } \\
\text { (Colicchia and } \\
\text { Strozzi,2012) }\end{array}$ & \begin{tabular}{|c|} 
SCM literatrue Review \\
(Seuring and Gold, \\
2012 ) \\
\end{tabular} & $\begin{array}{c}\text { Published SCM } \\
\text { literature Review } \\
(2000-2019)\end{array}$ & $\begin{array}{l}\text { SJR Impact } \\
\text { Factor } 2018\end{array}$ \\
\hline 1 & Journal of Operations Management & $\mathrm{x}$ & $\mathrm{x}$ & $\mathrm{x}$ & & 6.48 \\
\hline 2 & Journal of Supply Chain Management & & & & $\mathrm{x}$ & 6.44 \\
\hline 3 & Management Science & & $\mathrm{x}$ & & & 6.08 \\
\hline 4 & Omega: International Journal of Management Science & & & & $\mathrm{x}$ & 3.29 \\
\hline 5 & Production and Operations Management & & $\mathrm{x}$ & & $\mathrm{x}$ & 3.28 \\
\hline 6 & Transportation Research Part B: Methodological & & & & $\mathrm{x}$ & 2.92 \\
\hline 7 & International Journal of Management Reviews & & & $\mathrm{x}$ & $\mathrm{x}$ & 2.9 \\
\hline 8 & Transportation Research, Part C: Emerging Technologies & & & & $\mathrm{x}$ & 2.61 \\
\hline 9 & Journal of Business Logistics & $\mathrm{x}$ & & & & 2.49 \\
\hline 10 & International Journal of Production Economics & & $\mathrm{x}$ & $\mathrm{x}$ & & 2.48 \\
\hline 11 & International Journal of Physical Distribution and Logistics Management & $\mathrm{x}$ & & $\mathrm{x}$ & $\mathrm{x}$ & 2.41 \\
\hline 12 & Surveys in Operations Research and Management Science & & & & $\bar{x}$ & 2.24 \\
\hline 13 & European Journal of Operational Research & & $\mathrm{x}$ & & & 2.21 \\
\hline 14 & Transport Reviews & & & 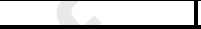 & $\mathrm{x}$ & 2.14 \\
\hline 15 & International Journal of Operations and Production Management & $\mathrm{x}$ & & $\mathrm{x}$ & $\mathrm{x}$ & 2.1 \\
\hline 16 & Supply Chain Management: An International Journal & $\mathrm{x}$ & $\mathrm{x}$ & $\mathrm{x}$ & & 2.1 \\
\hline 17 & Transportation Research Part A: Policy and Practice & & & $\overline{0}$ & $\mathrm{x}$ & 2.04 \\
\hline 18 & Transportation Research Part E: Logistics and Transportation Review & & & - & & 1.97 \\
\hline 19 & Computers and Operations Research & & & 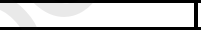 & $\mathrm{x}$ & 1.86 \\
\hline 20 & Corporate Social Responsibility and Environmental Management & & & & $\mathrm{x}$ & 1.67 \\
\hline 21 & Iournal of Cleaner Production & & & $\mathrm{x}$ & $\mathrm{x}$ & 1.62 \\
\hline 22 & International Journal of Production Research & & & $\mathrm{x}$ & $\mathrm{x}$ & 1.59 \\
\hline 23 & Transportation Research Part D: Transport and Environment & & & & $\mathrm{x}$ & 1.45 \\
\hline 24 & Production Planning and Control & & & & $\mathrm{x}$ & 1.43 \\
\hline 25 & Technological Forecasting and Social Change & & & & $\mathrm{x}$ & 1.42 \\
\hline 26 & Journal of Intelligent Manufacturing & & 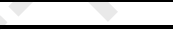 & & $\mathrm{x}$ & 1.39 \\
\hline 27 & Decision Science & & & & & 1.33 \\
\hline 28 & Expert Systems with Applications & - & E & & $\mathrm{x}$ & 1.19 \\
\hline 29 & International Journal of Logistics: Research and Applications & $\mathrm{x}$ & & & $\mathrm{x}$ & 1.05 \\
\hline 30 & Annals of Operations Research & & & & $\mathrm{x}$ & 1.03 \\
\hline 31 & IMA Journal of Management Mathematics & & & & $\mathrm{x}$ & 1.02 \\
\hline 32 & International Journal of Advanced Manufacturing Technology & & & & $\mathrm{x}$ & 0.99 \\
\hline 33 & International Journal of Logistics Management & $\mathrm{x}$ & & $\mathrm{x}$ & $\mathrm{x}$ & 0.871 \\
\hline 34 & Journal of Humanitarian Logistics and Supply Chain Management & & & & $\mathrm{x}$ & 0.84 \\
\hline 35 & International Transactions in Operational Research & & & & $\mathrm{x}$ & 0.83 \\
\hline 36 & Journal of the Operational Research Society & & $\mathrm{x}$ & & . & 0.82 \\
\hline 37 & Transportation Journal & $\mathrm{x}$ & & & & 0.81 \\
\hline 38 & Journal of Enterprise Information Management & & & & $\mathrm{x}$ & 0.69 \\
\hline 39 & International Journal of Productivity and Performance Management & & & $\mathrm{x}$ & & 0.64 \\
\hline 40 & Benchmarking & & & & $\mathrm{x}$ & 0.59 \\
\hline 41 & Sustainability & & & & $\mathrm{x}$ & 0.55 \\
\hline 42 & Logistics Research & & & & $\mathrm{x}$ & 0.51 \\
\hline 43 & IIMB Management Review & & & & $\mathrm{x}$ & 0.41 \\
\hline 44 & Journal of Industrial Engineering and Management & & & & $\mathrm{x}$ & 0.35 \\
\hline 45 & International Journal of Logistics Systems and Management & & & & $\mathrm{x}$ & 0.33 \\
\hline 46 & Risk Management & & & & $\mathrm{x}$ & 0.29 \\
\hline 47 & Management Review Quarterly & & & & $\mathrm{x}$ & 0.25 \\
\hline 48 & International Journal of Information Systems and Supply Chain Management & & & & $\mathrm{x}$ & 0.25 \\
\hline 49 & Quality - Access to Success & & & & $\mathrm{x}$ & 0.23 \\
\hline 50 & International Journal of Business Science and Applied Management & & & & $\mathrm{x}$ & 0.21 \\
\hline 51 & International Journal of Supply Chain Management & & & & $\mathrm{x}$ & 0.2 \\
\hline 52 & International Journal of Operations and Quantitative Management & & & & $\mathrm{x}$ & 0.13 \\
\hline 53 & Advanced Science Letters & & & & $\mathrm{x}$ & 0.12 \\
\hline 54 & International Journal of Applied Business and Economic Research & & & & $\mathrm{x}$ & 0.11 \\
\hline 55 & European Journal of Purchasing and Supply Management & & & $\bar{x}$ & & T \\
\hline 56 & Journal of Operations and Supply Chain Management & & & & $\mathrm{x}$ & 1 \\
\hline 57 & International Journal of Networking and Virtual Organizations & & & & $\mathrm{x}$ & 1 \\
\hline 58 & Journal of Advances in Management Research & & & & $\mathrm{x}$ & 1 \\
\hline 59 & The Journal of Business \& Industrial Marketing & & & & $\mathrm{x}$ & I \\
\hline 60 & IUP Journal of Supply Chain Management & & & & $\mathrm{x}$ & $T$ \\
\hline 61 & Journal of Supply Chain Management Systems & & & & $\mathrm{x}$ & 1 \\
\hline 62 & International Journal of Sustainable Strategic Management & & & & $\mathrm{x}$ & 1 \\
\hline 63 & Journal of Developing Areas & & & & $\mathrm{x}$ & 1 \\
\hline
\end{tabular}


Table A.3

The list of paradoxes, definitions, managerial insights, and paradox categories.

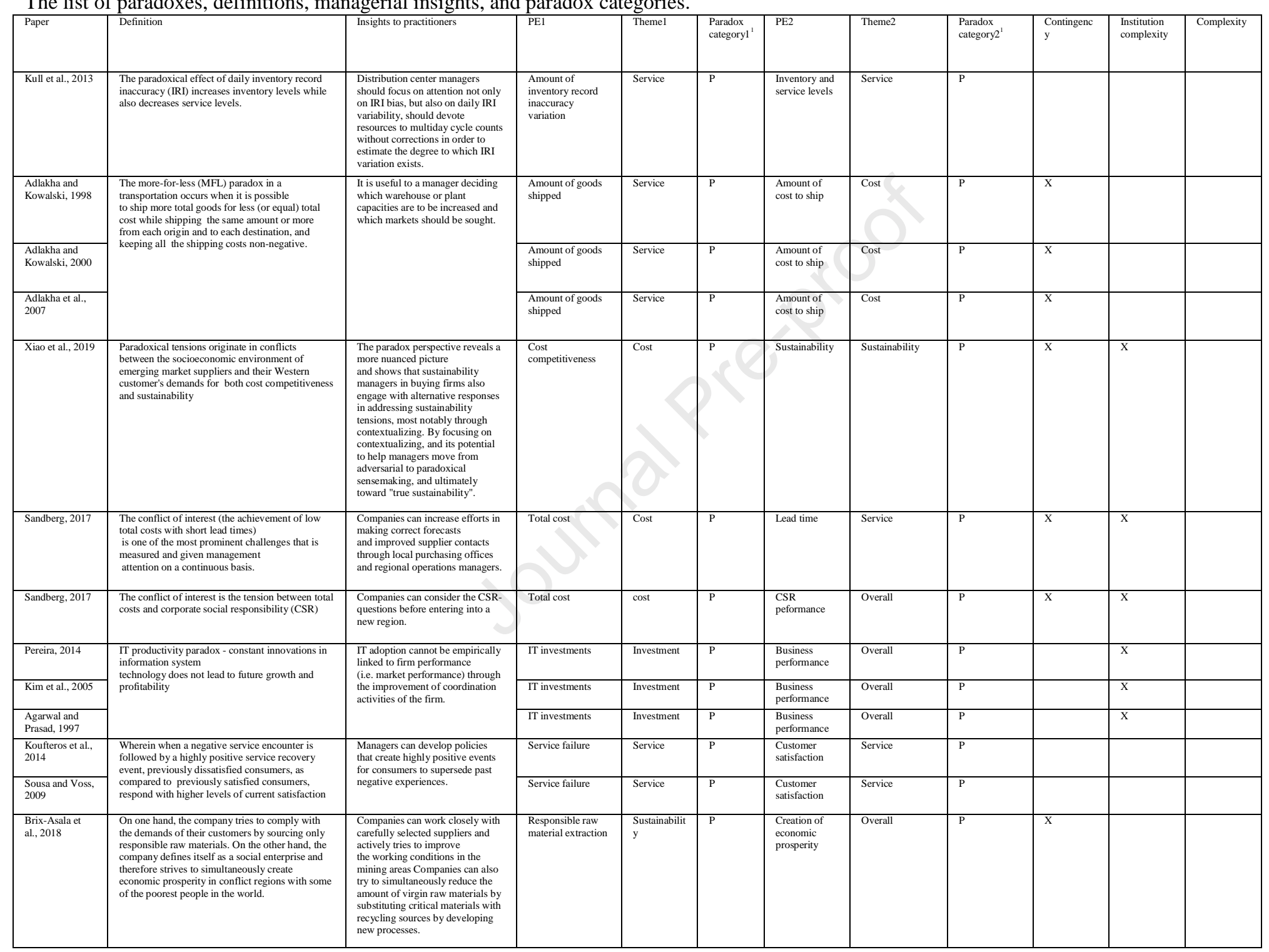




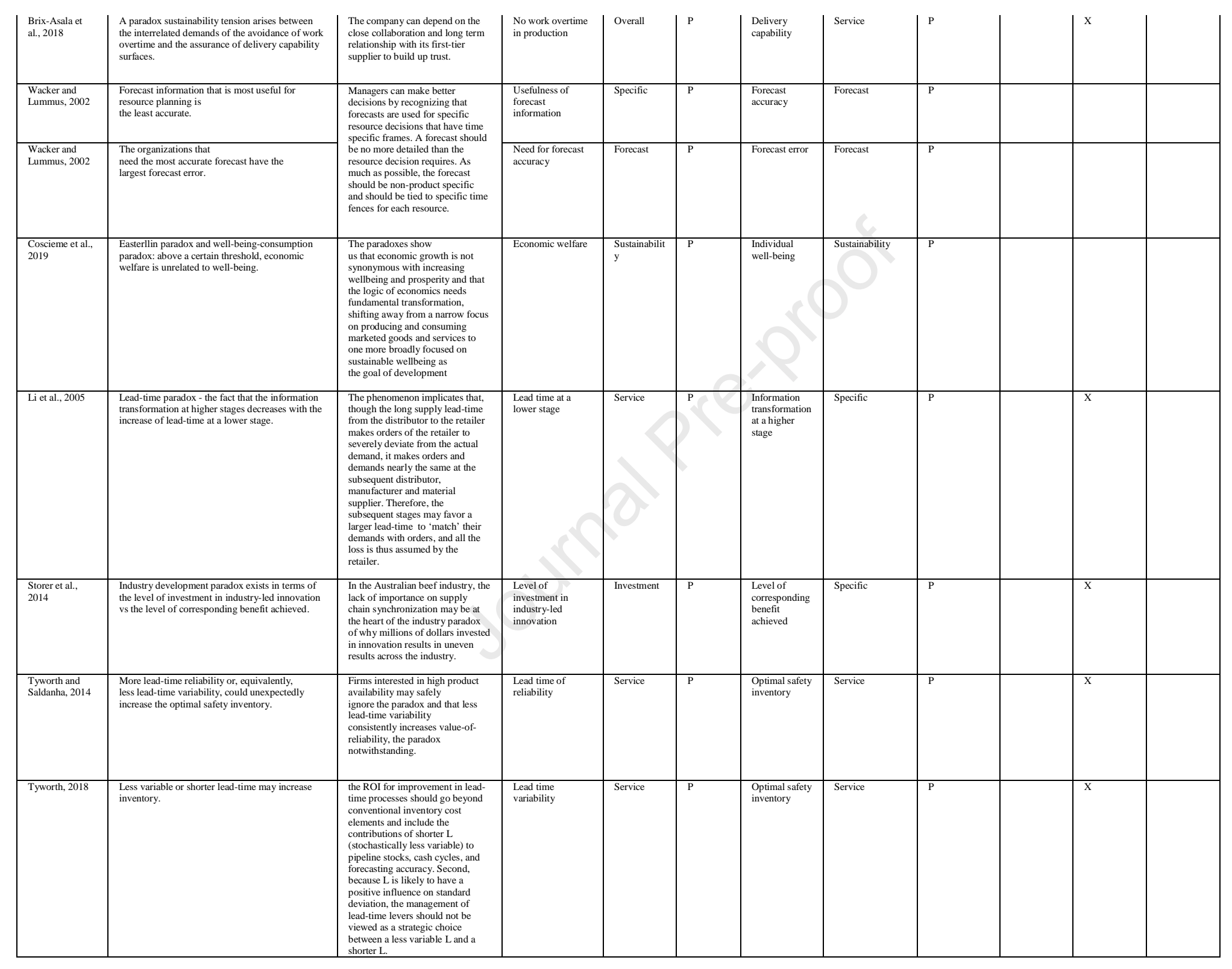




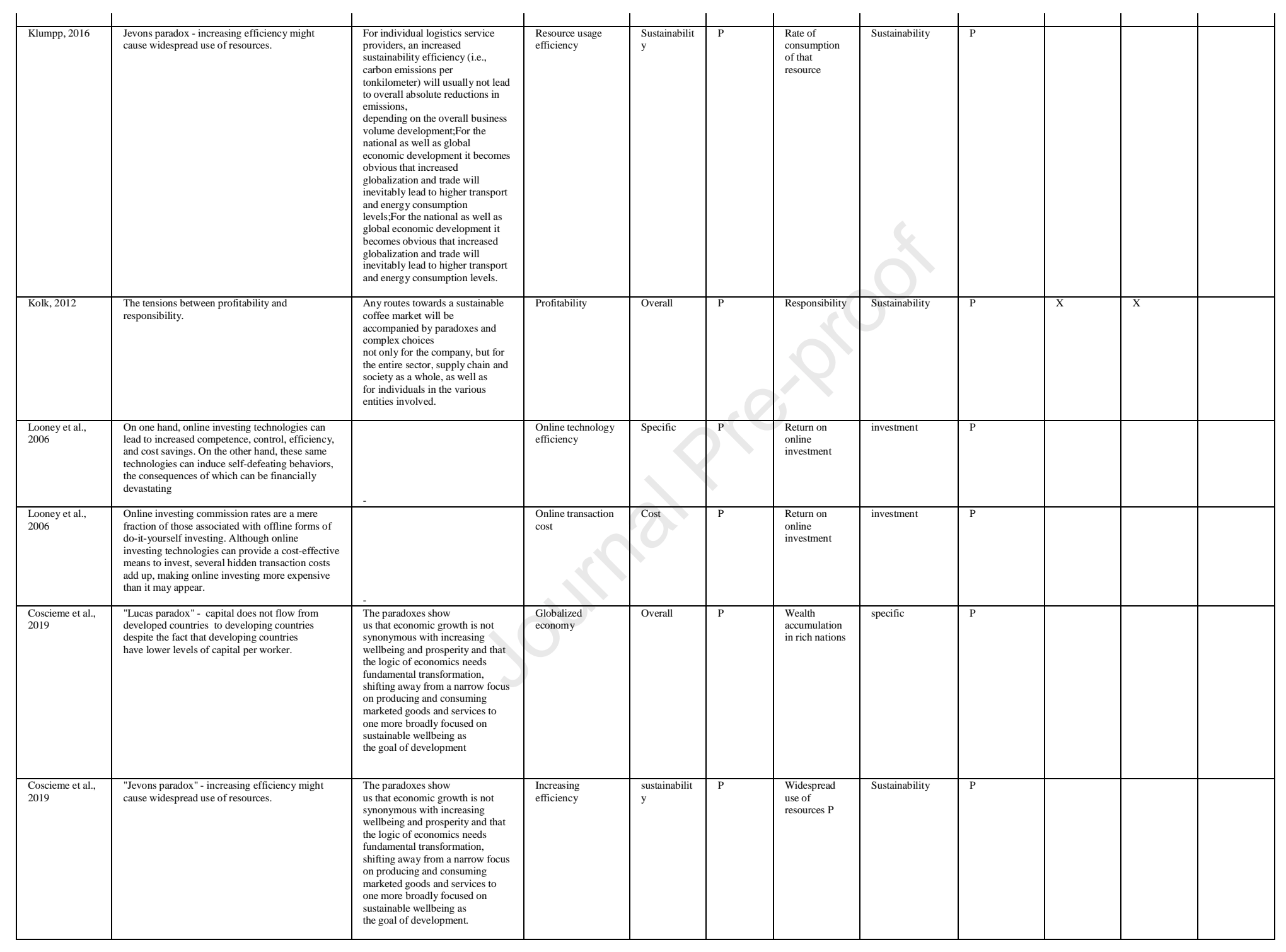




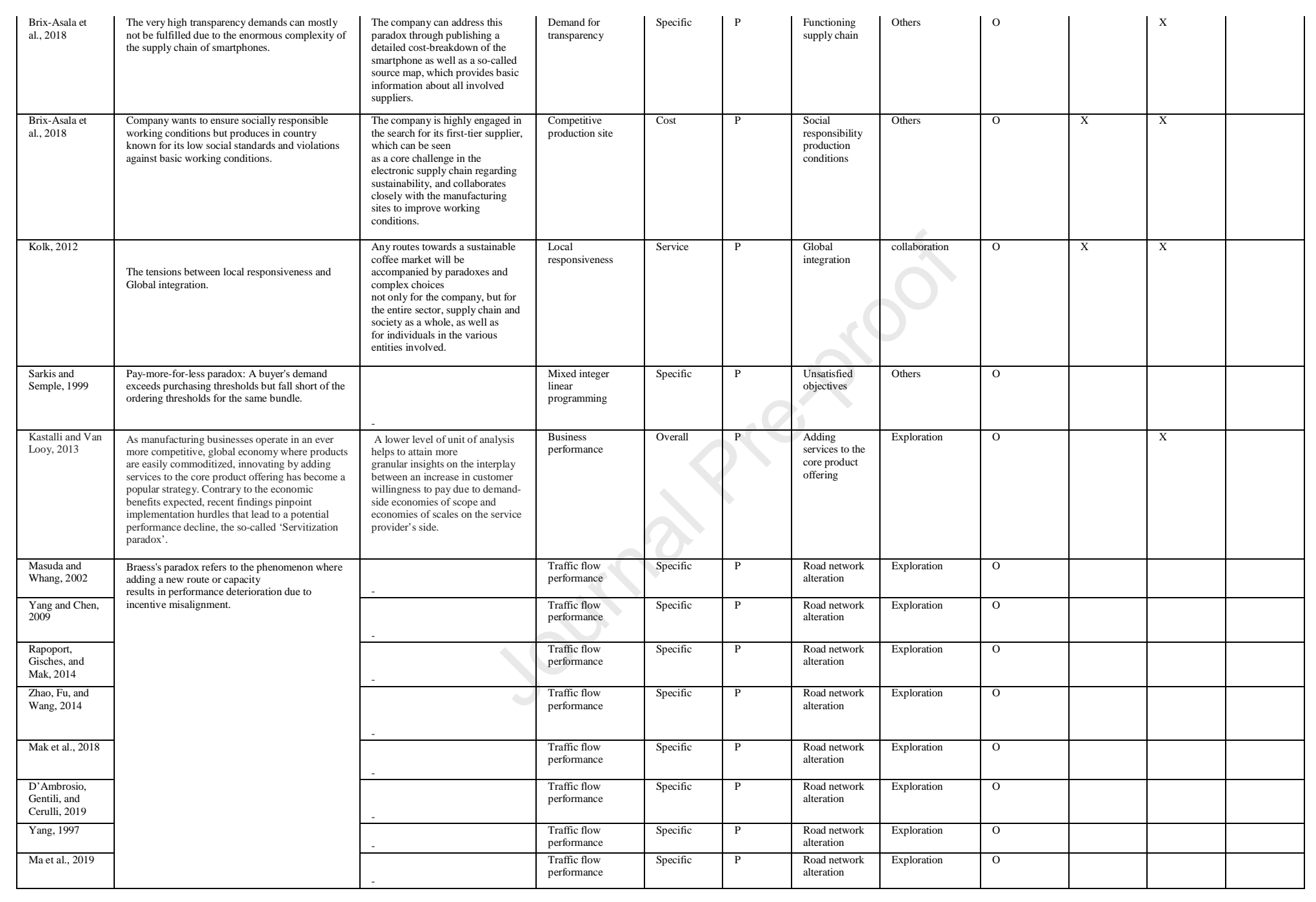




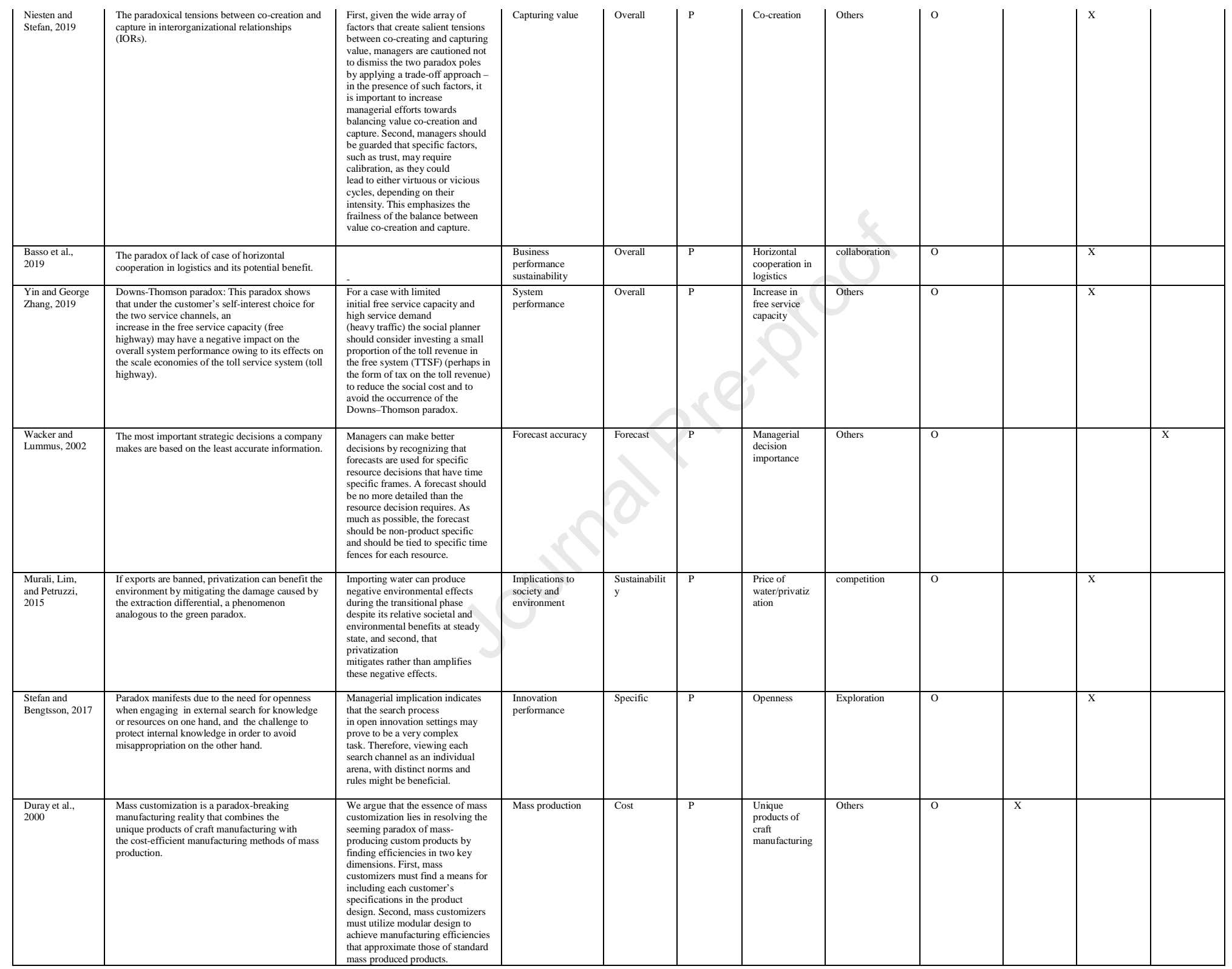




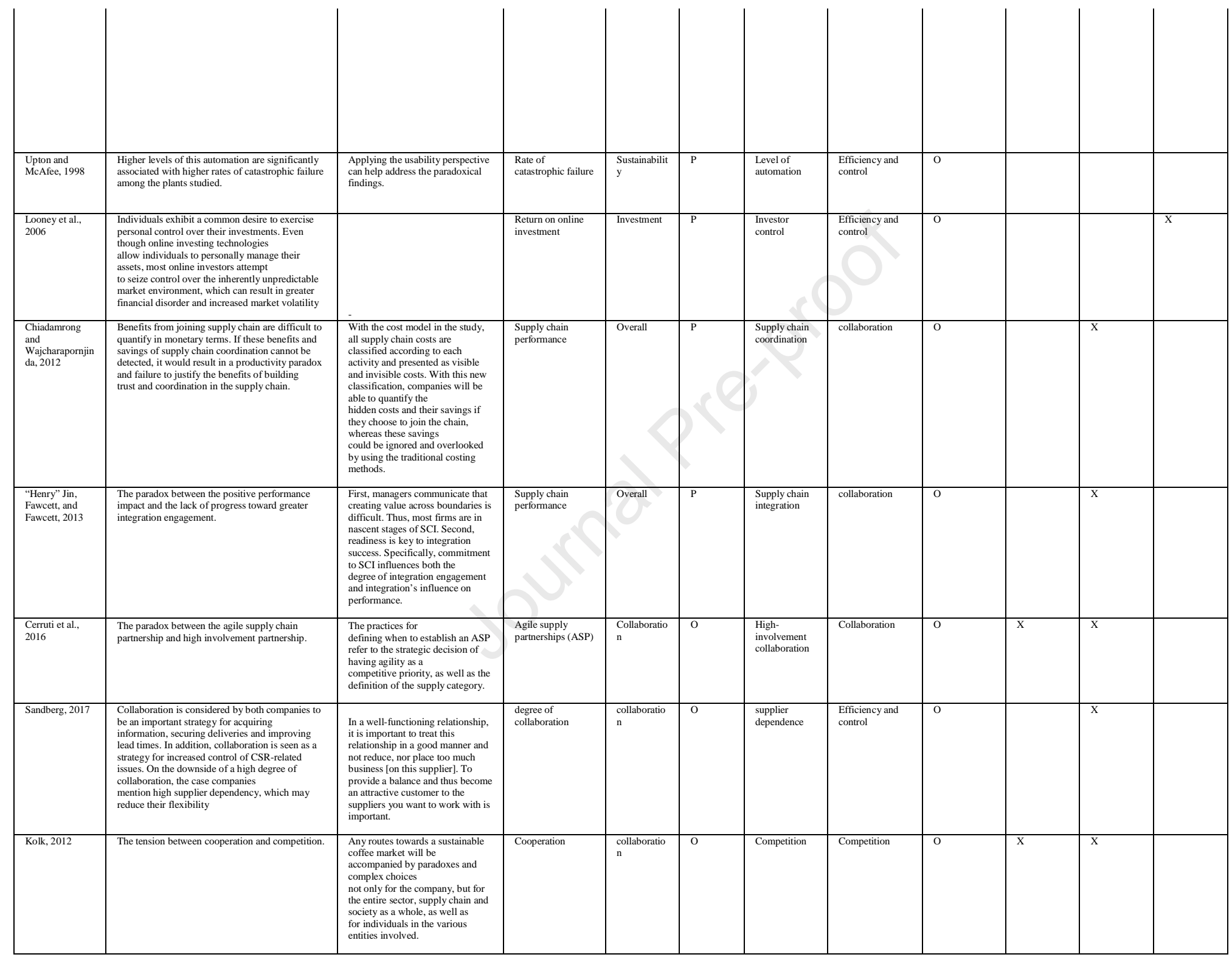




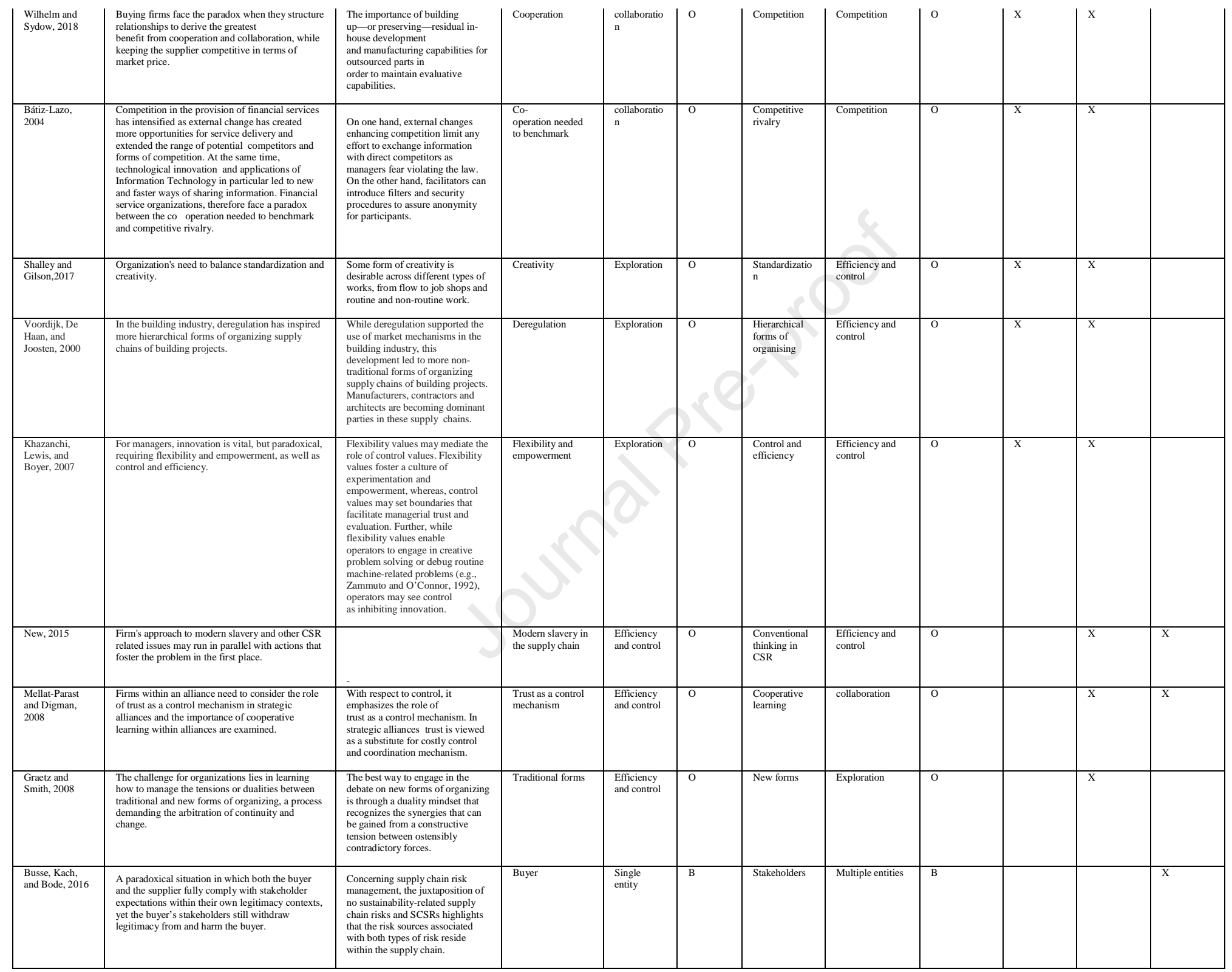




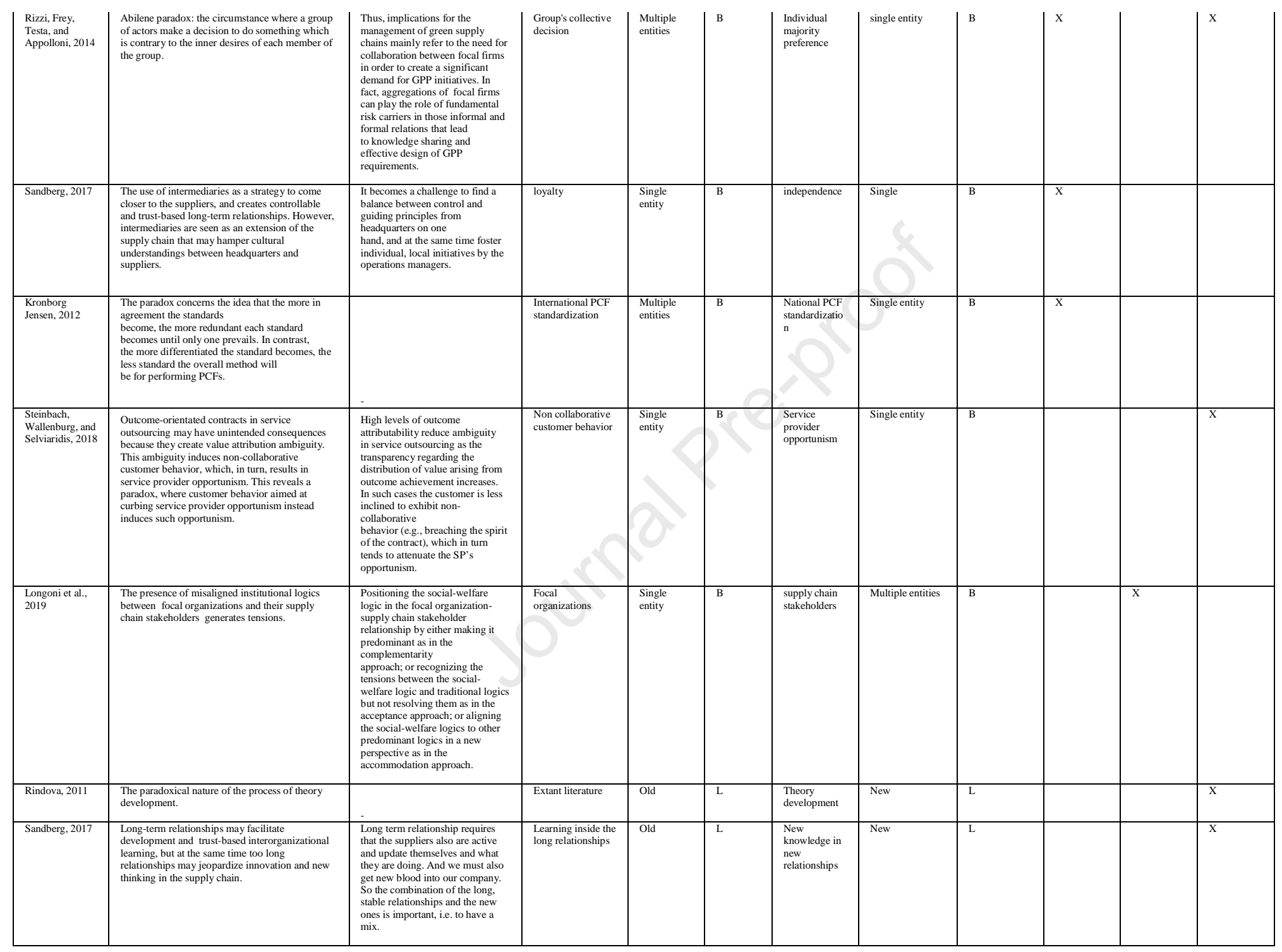




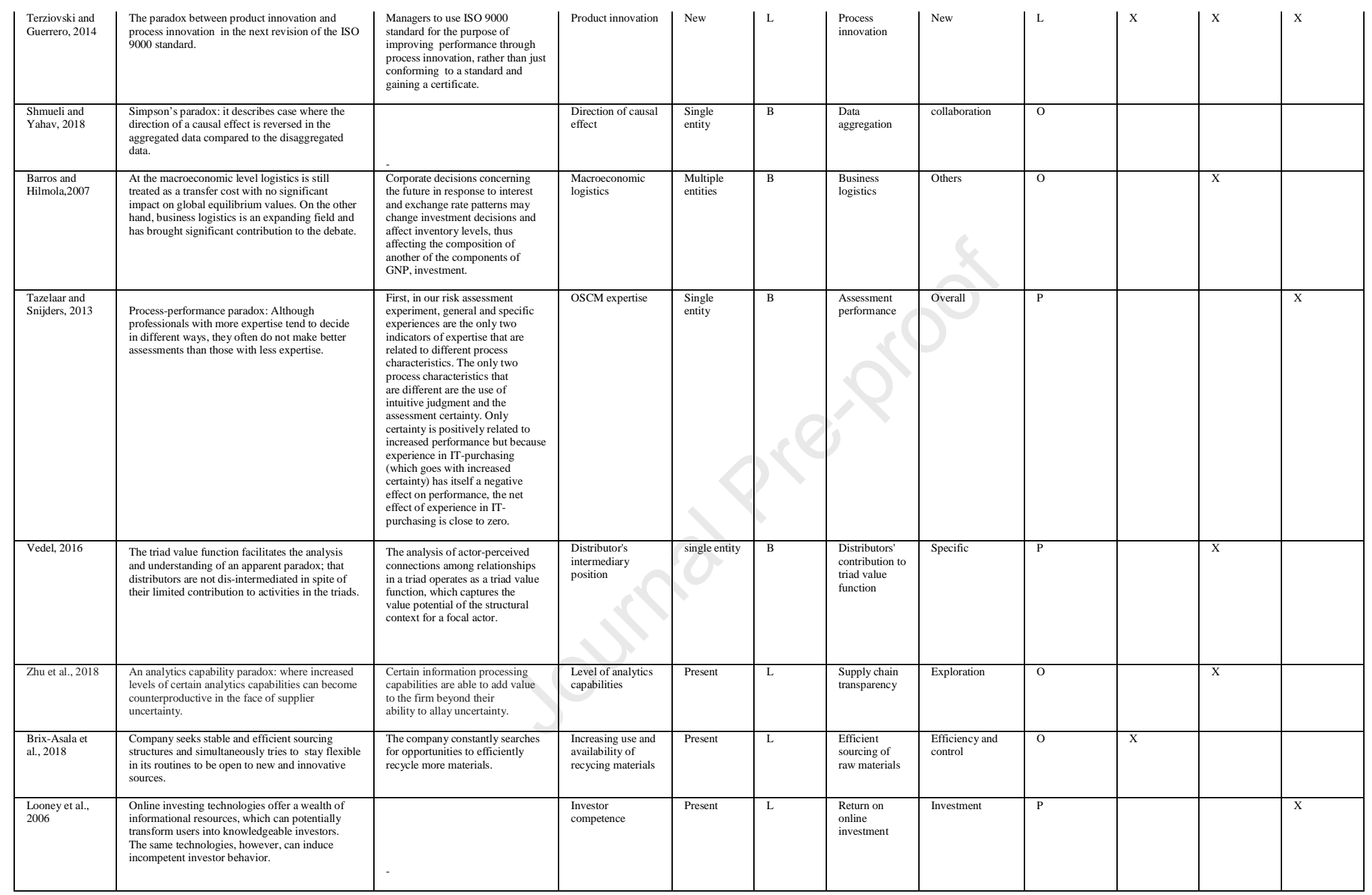

Note 1: P - Performing paradox: Tensions between multiple stakeholders' goals,

$O$ - Organizing paradox: Tensions between structuring and leading in organization;

L - Learning Paradox: Tensions between building upon and destroying the past to create future;

$B$ - Beloning paradox: Tensions between individual and collectively and between competing values,roles, and memberships. 


\section{REFERENCES}

Adlakha, V., Kowalski, K., 1998. A quick sufficient solution to the more-for-less paradox in the transportation problem. Omega, 26(4), 541-547.

Adlakha, V., Kowalski, K., 2000. A note on the procedure MFL for a more-for-less solution in transportation problems. Omega, 28(4), 481-483.

Adlakha, V., Kowalski, K., Vemuganti, R. R., Lev, B., 2007. More-for-less algorithm for fixed-charge transportation problems. Omega, 35(1), 116-127.

Agarwal, R., Prasad, J., 1997. The role of innovation characteristics and perceived voluntariness in the acceptance of information technologies. Decision sciences, 28(3), 557-582.

Anderson, P., 1999. Perspective: Complexity theory and organization science. Organization science, 10(3), $216-232$.

Barros, L., Hilmola, O.P., 2007. Quantifying and modelling logistics at business and macro levels. International Journal of Logistics Systems and Management, 3(4), 382-394.

Basso, F., D'Amours, S., Rönnqvist, M., Weintraub, A., 2019. A survey on obstacles and difficulties of practical implementation of horizontal collaboration in logistics. International Transactions in Operational Research, 26(3), 775-793.

Bátiz-Lazo, B., 2004. Benchmarking financial services and online innovations. Benchmarking: An International Journal, 11(5), 431-446.

Boon-itt, S., Wong, C. Y., Wong, C. W., 2017. Service supply chain management process capabilities: Measurement development. International Journal of Production Economics, 193, 1-11.

Brix-Asala, C., Geisbüsch, A.K., Sauer, P., Schöpflin, P., Zehendner, A., 2018. Sustainability tensions in supply chains: a case study of paradoxes and their management. Sustainability, 10(2), 424.

Busse, C., Kach, A.P., Bode, C., 2016. Sustainability and the false sense of legitimacy: How institutional distance augments risk in global supply chains. Journal of Business Logistics, 37(4), 312-328.

Cerruti, C., Mena, C., Skipworth, H., Tavoletti, E., 2016. Characterizing agile supply partnerships in the fashion industry. International Journal of Operations \& Production Management, 36(8), 923-947.

Chae, B. K., 2012. An evolutionary framework for service innovation: Insights of complexity theory for service science. International journal of production economics, 135(2), 813-822.

Chakuu, S., Masi, D., Godsell, J., 2019. Exploring the relationship between mechanisms, actors and instruments in supply chain finance: A systematic literature review. International Journal of Production Economics, 216, $35-53$.

Chiadamrong, N., Wajcharapornjinda, P., 2012. Developing an economic cost model for quantifying supply chain costs. International Journal of Logistics Systems and Management, 13(4), 540-571.

Choi, T.Y., Eboch, K., 1998. The TQM paradox: relations among TQM practices, plant performance, and customer satisfaction. Journal of Operations management, 17(1), 59-75.

Cohen, J., 1960. A coefficient of agreement for nominal scales. Educational and psychological measurement, 20(1), $37-46$.

Colicchia, C., Strozzi, F., 2012. Supply chain risk management: a new methodology for a systematic literature 
review. Supply Chain Management: An International Journal, 17(4), 403-418.

Coscieme, L., Sutton, P., Mortensen, L. F., Kubiszewski, I., Costanza, R., Trebeck, K., ..., Fioramonti, L., 2019. Overcoming the Myths of Mainstream Economics to Enable a New Wellbeing Economy. Sustainability, 11(16), 4374.

Cunha, M. P. E., Fortes, A., Gomes, E., Rego, A., Rodrigues, F., 2019. Ambidextrous leadership, paradox and contingency: evidence from Angola. The International Journal of Human Resource Management, 30(4), $702-727$.

D'Ambrosio, C., Gentili, M., Cerulli, R., 2019. The optimal value range problem for the interval (immune) transportation problem. Omega, 95, 102059

Durach, C.F., Kembro, J., Wieland, A., 2017. A new paradigm for systematic literature reviews in supply chain management. Journal of Supply Chain Management, 53(4), 67-85.

Duray, R., Ward, P.T., Milligan, G.W., Berry, W.L., 2000. Approaches to mass customization: configurations and empirical validation. Journal of operations management, 18(6), 605-625.

Fabbe-Costes, N., Jahre, M., 2008. Supply chain integration and performance: a review of the evidence. The International Journal of Logistics Management, 19(2), 130-154.

Fiedler, F., 2005. Contingency Theory of Leadership'. Organizational behavior: Essential theories of motivation and leadership, 1, 232.

Frank, M., 1981. The braess paradox. Mathematical Programming, 20(1), 283-302.

Glock, C. H., Grosse, E. H., Ries, J. M., 2017. Reprint of "Decision support models for supplier development: Systematic literature review and research agenda". International Journal of Production Economics, 194, 246-260.

Graetz, F., Smith, A.C., 2008. The role of dualities in arbitrating continuity and change in forms of organizing. International Journal of Management Reviews, 10(3), 265-280.

Greenwood, R., Raynard, M., Kodeih, F., Micelotta, E. R., Lounsbury, M., 2011. Institutional complexity and organizational responses. Academy of Management annals, 5(1), 317-371.

Halldórsson, Á., Kotzab, H., Mikkola, J. H., Skjøtt-Larsen, T., 2007. Complementary theories to supply chain management. Supply chain management: An international journal, 12(4), 284-296.

Halldórsson, Á., Hsuan, J., Kotzab, H., 2015. Complementary theories to supply chain management revisitedfrom borrowing theories to theorizing. Supply Chain Management: An International Journal, 20(6), 574586.

"Henry" Jin, Y., Fawcett, A.M., Fawcett, S.E., 2013. Awareness is not enough: Commitment and performance implications of supply chain integration. International Journal of Physical Distribution \& Logistics Management, 43(3), 205-230.

Kalchschmidt, M., 2012. Best practices in demand forecasting: Tests of universalistic, contingency and configurational theories. International Journal of Production Economics, 140(2), 782-793.

Kastalli, I.V., Van Looy, B., 2013. Servitization: Disentangling the impact of service business model innovation manufacturing firm performance. Journal of Operations Management, 31(4), 169-180.

Keller, J., Sadler - Smith, E., 2019. Paradoxes and Dual Processes: A Review and Synthesis. International Journal of Management Reviews, 21(2), 162-184. 
Khazanchi, S., Lewis, M.W., Boyer, K.K., 2007. Innovation-supportive culture: The impact of organizational values on process innovation. Journal of operations management, 25(4), 871-884.

Kim, D., Tamer Cavusgil, S., Calantone, R.J., 2005. The role of information technology in supply-chain relationships: does partner criticality matter? Journal of Business \& Industrial Marketing, 20(4/5), 169-178.

Klumpp, M., 2016. To green or not to green: A political, economic and social analysis for the past failure of green logistics. Sustainability, 8(5), p.441.

Kolk, A., 2012. Towards a sustainable coffee market: Paradoxes faced by a multinational company. Corporate Social Responsibility and Environmental Management, 19(2), 79-89.

Koufteros, X., Droge, C., Heim, G., Massad, N.,Vickery, S.K., 2014. Encounter satisfaction in e-tailing: are the relationships of order fulfillment service quality with its antecedents and consequences moderated by historical satisfaction?. Decision Sciences, 45(1), 5-48.

Kronborg Jensen, J., 2012. Product carbon footprint developments and gaps. International Journal of Physical Distribution \& Logistics Management, 42(4), 338-354.

Kull, T.J., Barratt, M., Sodero, A.C.,Rabinovich, E., 2013. Investigating the effects of daily inventory record inaccuracy in multichannel retailing. Journal of Business Logistics, 34(3), 189-208.

Lewis, M.W., 2000. Exploring paradox: Toward a more comprehensive guide. Academy of Management review, 25(4), 760-776.

Lewis, M.W., Smith, W.K., 2014. Paradox as a metatheoretical perspective: Sharpening the focus and widening the scope. The Journal of Applied Behavioral Science, 50(2), 127-149.

Li, G., Wang, S., Yan, H., Yu, G., 2005. Information transformation in a supply chain: a simulation study. Computers \& Operations Research, 32(3), 707-725.

Longoni, A., Luzzini, D., Pullman, M., Habiague, M., 2019. Business for society is society, s business: Tension management in a migrant integration supply chain. Journal of Supply Chain Management,55(4), 3-33.

Looney, C.A., Valacich, J.S., Todd, P.A., Morris, M.G., 2006. Paradoxes of online investing: Testing the influence of technology on user expectancies. Decision Sciences, 37(2), 205-246.

Luscher, L.S., Lewis, M. and Ingram, A., 2006. The social construction of organizational change paradoxes. Journal of Organizational Change Management, 19, pp. 491-502.

Ma, C., Cai, Q., Alam, S., Sridhar, B., Duong, V. N., 2019. Airway network management using Braess's Paradox. Transportation Research Part C: Emerging Technologies, 105, 565-579.

Mak, V., Seale, D.A., Gisches, E.J., Yang, R., Cheng, M., Moon, M., Rapoport, A., 2018. The Braess paradox and coordination failure in directed networks with mixed externalities. Production and Operations Management, 27(4), 717-733.

Masae, M., Glock, C. H., Grosse, E. H., 2020. Order picker routing in warehouses: A systematic literature review. International Journal of Production Economics, 224, 107564.

Masuda, Y., Whang, S., 2002. Capacity management in decentralized networks. Management Science, 48(12), 1628 1634.

Matthews, L., Power, D., Touboulic, A.,Marques, L., 2016. Building bridges: Toward alternative theory of sustainable supply chain management. Journal of supply chain management, 52(1), 82-94. 
Mellat-Parast, M., Digman, L. A., 2008. Learning: the interface of quality management and strategic alliances. International Journal of Production Economics, 114(2), 820-829.

Mokhtar, A. R. M., Genovese, A., Brint, A., Kumar, N., 2019. Supply chain leadership: A systematic literature review and a research agenda. International Journal of Production Economics, 216, 255-273.

Murali, K., Lim, M.K., Petruzzi, N.C., 2015. Municipal groundwater management: optimal allocation and control of a renewable natural resource. Production and Operations Management, 24(9), 1453-1472.

New, S.J., 2015. Modern slavery and the supply chain: the limits of corporate social responsibility? Supply Chain Management: An International Journal, 20(6), 697-707.

Niesten, E., Stefan, I., 2019. Embracing the Paradox of Interorganizational Value Co - creation - Value Capture: A Literature Review towards Paradox Resolution. International Journal of Management Reviews, 21(2), 231255.

Nilsson, F., 2006. Logistics management in practice-towards theories of complex logistics. The International Journal of Logistics Management, 17(1), 38-54.

Nilsson, F. R., 2019. A complexity perspective on logistics management Rethinking assumptions for the sustainability era. The International Journal of Logistics Management,30(3), 681-698.

Nilsson, F., Christopher, M., 2018. Rethinking logistics management Towards a strategic mind-set for logistics effectiveness and innovation. Emergence: Complexity \& Organization, 20(2),1-24.

Nilsson, F., Gammelgaard, B., 2012. Moving beyond the systems approach in SCM and logistics research. International Journal of Physical Distribution \& Logistics Management, 42(8/9), 764-783.

Pereira, M.J., 2004. Impacts of information systems and technology on productivity and competitiveness of the Portuguese banking sector: an empirical study. International Transactions in Operational Research, 11(1), 43-62.

Philip, A., 1999. Complexity theory and organization science. Organization science, 10(3), 216-232.

Rapoport, A., Gisches, E.J., Mak, V., 2014. Distributed decisions in networks: Laboratory study of routing splittable flow. Production and Operations Management, 23(2), 314-331.

Rindova, V., 2011. Moving from ideas to a theoretical contribution: Comments on the process of developing theory in organizational research. Journal of Supply Chain Management, 47(2),19-21.

Rizzi, F., Frey, M., Testa, F., Appolloni, A., 2014. Environmental value chain in green SME networks: the threat of the Abilene paradox. Journal of cleaner production, 85, 265-275.

Sandberg, E., 2017. Introducing the paradox theory in logistics and SCM research-examples from a global sourcing context. International Journal of Logistics Research and Applications, 20(5), 459-474.

Sarkis, J., Semple, J.H., 1999. Vendor selection with bundling: A comment. Decision Sciences, 30(1), $265-271$.

Schad, J., Lewis, M.W., Raisch, S., Smith, W.K., 2016. Paradox research in management science: Looking back to move forward. The Academy of Management Annals, 10(1), 5-64.

Schad, J., Lewis, M.W., Smith, W.K., 2019. Quo vadis, paradox? Centripetal and centrifugal forces in theory development. Strategic Organization, 17(1), 107-119.

Schmidt, C.G., Foerstl, K., Schaltenbrand, B., 2017. The supply chain position paradox: green practices and firm 
performance. Journal of Supply Chain Management, 53(1), 3-25.

Scott, W. R., Davis, G. F., 2015. Organizations and organizing: Rational, natural and open systems perspectives. Routledge.

Seuring, S., Gold, S., 2012. Conducting content-analysis based literature reviews in supply chain management. Supply Chain Management: An International Journal, 17(5), 544-555.

Shalley, C.E., Gilson, L.L., 2017. Creativity and the management of technology: Balancing creativity and standardization. Production and Operations Management, 26(4), 605-616.

Shmueli, G., Yahav, I., 2018. The Forest or the Trees? Tackling Simpson's Paradox with Classification Trees. Production and Operations Management, 27(4), 696-716.

Smith, W. K., Lewis, M. W., 2011. Toward a theory of paradox: A dynamic equilibrium model of organizing. Academy of management Review, 36(2), 381-403.

Smith, W. K., Tracey, P., 2016. Institutional complexity and paradox theory: Complementarities of competing demands. Strategic Organization, 14(4), 455-466.

Smith, W.K., Lewis, M.W., Jarzabkowski, P., Langley, A. (Eds)., 2017. The Oxford handbook of organizational paradox. Oxford, UK: Oxford University Press.

Sousa, R., Voss, C.A., 2009. The effects of service failures and recovery on customer loyalty in e-services: An empirical investigation. International Journal of Operations \& Production Management, 29(8), 834-864.

Stefan, I., Bengtsson, L., 2017. Unravelling appropriability mechanisms and openness depth effects on firm performance across stages in the innovation process. Technological Forecasting and Social Change, 120, $252-260$

Steinbach, T., Wallenburg, C.M., Selviaridis, K., 2018. Me, myself and I: Non-collaborative customer behavior in service outsourcing-the key role of outcome orientation and outcome attributability. International Journal of Operations \& Production Management, 38(7), 1519-1539.

Storer, M., Hyland, P., Ferrer, M., Santa, R., Griffiths, A., 2014. Strategic supply chain management factors influencing agribusiness innovation utilization. The International Journal of Logistics Management, 25(3), $487-521$.

Tazelaar, F., Snijders, C., 2013. Operational risk assessments by supply chain professionals: Process and performance. Journal of Operations Management, 31(1-2), 37-51.

Terziovski, M., Guerrero, J.L., 2014. ISO 9000 quality system certification and its impact on product and process innovation performance. International Journal of Production Economics, 158, 197-207.

Thomé, A. M. T., Scavarda, L. F., \& Scavarda, A. J., 2016. Conducting systematic literature review in operations management. Production Planning \& Control, 27(5), 408-420.

Tyworth, J.E., 2018. A note on lead-time paradoxes and a tale of competing prescriptions. Transportation Research Part E: Logistics and Transportation Review, 109(C), 139-150.

Tyworth, J.E., Saldanha, J., 2014. The lead-time reliability paradox and inconsistent value-of-reliability estimates. Transportation Research Part E: Logistics and Transportation Review, 70, 76-85.

Touboulic, A., Matthews, L., Marques, L., 2018. On the road to carbon reduction in a food supply network: a 
complex adaptive systems perspective. Supply Chain Management: An International Journal, 23(4), 313335 .

Upton, D.M., McAfee, A.P., 1998. Computer integration and catastrophic process failure in flexible production: An empirical investigation. Production and Operations Management, 7(3), 265-281.

Vedel, M., 2016. The triad value function-theorizing the value potential of connected relationships. Journal of Business \& Industrial Marketing, 31(7), 849-860.

Voordijk, H., De Haan, J., Joosten, G.J., 2000. Changing governance of supply chains in the building industry: a multiple case study. European Journal of Purchasing \& Supply Management, 6(3-4), 217-225.

Wacker, J.G., Lummus, R.R., 2002. Sales forecasting for strategic resource planning. International Journal of Operations \& Production Management, 22(9), 1014-1031.

Wilhelm, M., Sydow, J., 2018. Managing coopetition in supplier networks-A paradox perspective. Journal of Supply Chain Management, 54(3), 22-41.

Xiao, C., Wilhelm, M., van der Vaart, T., van Donk, D.P., 2019. Inside the buying firm: Exploring responses to paradoxical tensions in sustainable supply chain management. Journal of Supply Chain Management, 55(1), 3-20.

Yang, H., 1997. Sensitivity analysis for the elastic-demand network equilibrium problem with applications. Transportation Research Part B: Methodological, 31(1), 55-70.

Yang, C., Chen, A., 2009. Sensitivity analysis of the combined travel demand model with applications. European Journal of Operational Research, 198(3), 909-921.

Yin, X., George Zhang, Z., 2019. On Downs-Thomson paradox in two-tier service systems with a fast pass and revenue-based capacity investment. Journal of the Operational Research Society, 1-14.

Zhao, C., Fu, B., Wang, T., 2014. Braess paradox and robustness of traffic networks under stochastic user equilibrium. Transportation Research Part E: Logistics and Transportation Review, 61, 135-141.

Zhu, S., Song, J., Hazen, B.T., Lee, K., Cegielski, C., 2018. How supply chain analytics enables operational supply chain transparency: An organizational information processing theory perspective. International Journal of Physical Distribution \& Logistics Management, 48(1), 47-6 